UNITED STATES

DEPARTMENT OF THE INTERIOR

GEOLOGICAL SURVEY

PETROLEUM POTENTIAL, GEOLOGIC HAZARDS, AND TECHNOLOGY

FOR EXPLORATION IN THE OUTER CONTINENTAL SHELF

OF THE GULF OF ALASKA TERTIARY PROVINCE

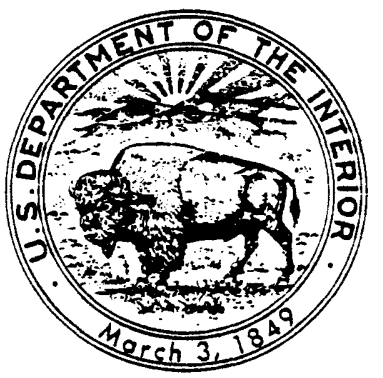

OPEN-FILE REPORT $78-490$

This report is preliminary and has not

been edited or reviewed for conformity

with Geological Survey standards and nomenclature

Menlo Park. California

June 1978 


\section{CONTENTS}

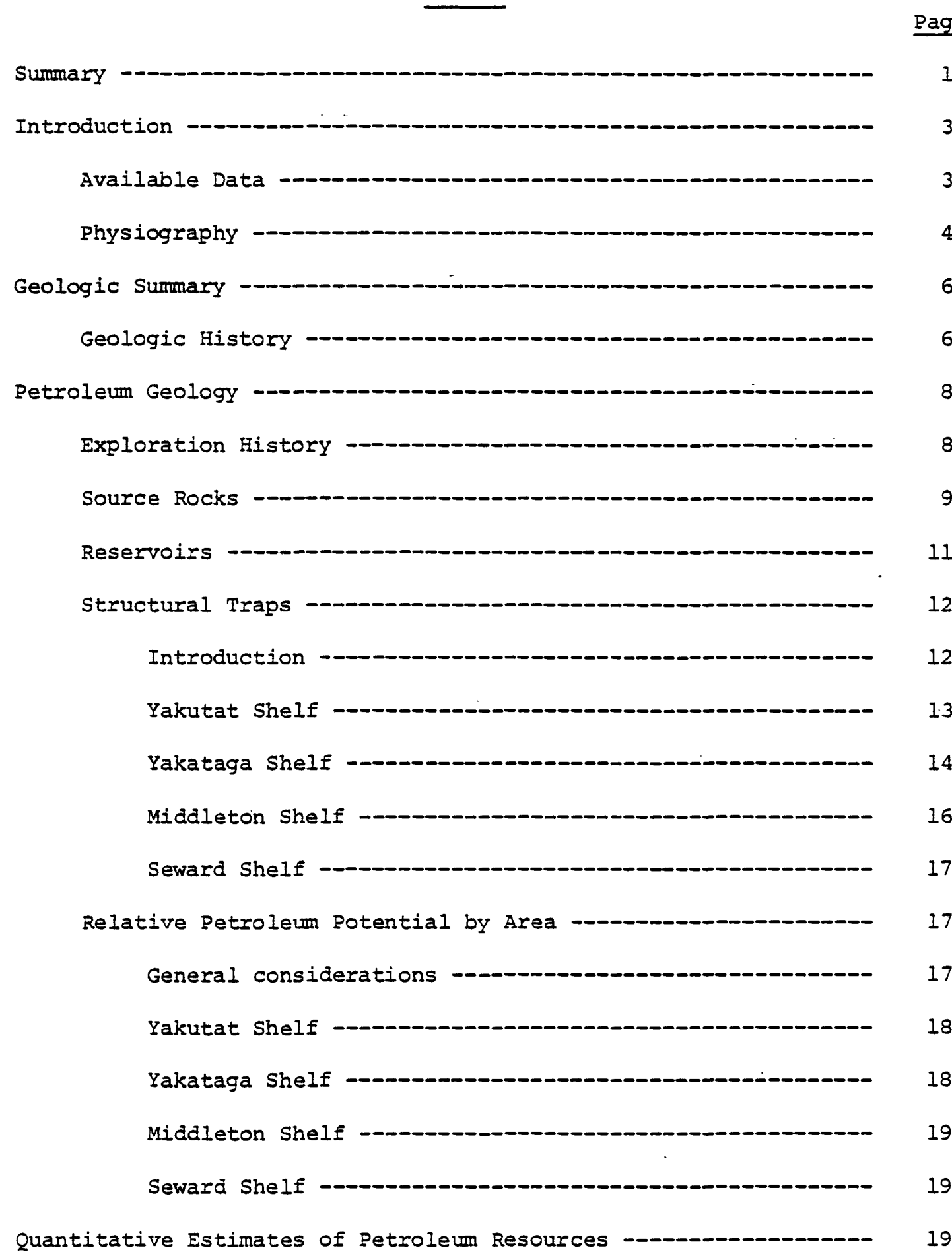


Geologic Hazards - 21

General Statement - 21

Seismic History - 21

Faulting and Warping - 22

Tsunamis - 23

Earthquake Recurrence and Seismic Gaps 23

Submarine Slumps and Slides

Gas in Sediments 25

Sediment Thickness - 25

Bedforms - 25

Other Hazards - 26

Technology for Exploration 26

Drill Rig Availability - 27

Comparison with North Sea Development 27

OCS Drilling Experience 29

Finances - 29

References Cited 30

Table

Table 1. Wells drilled for petroleum and stratigraphic data in the Gulf of Alaska Tertiary Province Outer

Continental Shelf 


\section{Illustrations}

Figure 1. Index map of Gulf of Alaska Tertiary Province and adjacent areas showing place names.

2. Map showing general geologic features of the Gulf of Alaska Tertiary province.

3. Tentative correlation of onshore rock units in Gulf of Alaska Tertiary Province.

4. Thickness and suggested stratigraphic relations of outcrop sections and onshore wells in the Gulf of Alaska Tertiary Province.

5. Structure, Yakutat shelf

6. Structure, Yakataga shelf

7. Structure, Midaleton shelf

8. Simplified interpretive line drawings

9. Lognormal probability distribution of the undiscovered recoverable oil and gas resources for the northern Gulf of Alaska continental shelf.

10. Map showing locations of earthquake epicenters and late Cenozoic faults.

11. Environmental hazards of the Yakutat shelf.

12. Environmental hazards of the Yakataga shelf and part of the Yakutat shelf.

13. Environmental hazards of the Middleton shelf. 


\title{
Petroleum Potential, Geologic Hazards, and Technology \\ for Exploration in the Outer Continental Shelf of the Gulf of Alaska Tertiary Province
}

\section{By}

\author{
George Plafker, T. R. Bruns, P. R. Carlson, B. F. Molnia, \\ E. W. Scott, Rodger Kahler, and Charles Wilson
}

\section{SUMMARY}

This report is intended to provide a preliminary assessment of the geologic framework, petroleum potential, environmental geology, and technology for development for the second tier ocs lease sale in the northern Gulf of Alaska. It is based largely on the pre-nomination report (Plafker and others, 1975) prepared for the initial northern Gulf of Alaska lease sale No. 39 held in April 1976. The earlier report has been modified to incorporate pertinent data that has become available since 1975.

The Gulf of Alaska Tertiary Province is a continental margin basin $560 \mathrm{mi}(900 \mathrm{~km})$ long by $125 \mathrm{mi}(200 \mathrm{~km})$ wide that is made up almost entirely of a sequence of clastic rocks in excess of $32,800 \mathrm{ft}(10,000 \mathrm{~m})$ in cumulative thickness. About $52,000 \mathrm{~km}^{2}\left(20,000 \mathrm{mi}^{2}\right)$ of the Tertiary Province lies offshore where it extends beneath the continental shelf and slope between Cross Sound on the east and Amatuli Trough on the west. Petroleum seepages and petroliferous rocks locally occur onshore in the province. Between 1954 and 1969, 22 unsuccessful wells were drilled onshore and one was drilled offshore near Middleton Island on State of Alaska land. Since oCS Sale No. 39, nine dry offshore wells have been drilled on the Yakataga shelf. The wells onshore and the Middleton Island well have been unsuccessful because structure is complex and because suitable sand- 
stone reservoir rocks have not been found in favorable structural positions near the middle Tertiary petroleum source beds. Data for the oCs wells are not yet publicly available.

Based on the drilling record to date and regional stratigraphic and structural considerations, the potential for finding hydrocarbons in commercial quantities is poor. The major untested prospective area is along the flanks of the Fairweather Ground structural high on the Yakutat shelf which is bordered on the northeast by a deep basin. This is a very large feature that has the potential for extensive combination structural and stratigraphic traps along its flanks. The Yakataga shelf has the thickest Tertiary section, the best anticlinal structures, and indications of petroleum in the adjacent onshore in the form of seeps and shows in wells. Virtually all the accessible large structures have been unsuccessfully tested by at least one deep exploratory well. Although petroleum may yet be found on the Yakataga shelf, the potential for very large commercial discoveries is not good. The petroleum potential of the Middleton and Seward shelves is considered to be very poor because structure is complex, the Neogene section is commonly greatly attenuated, and the section penetrated in the Middleton Island well shows little promise for suitable souree or reservoir beds.

Environmental hazards in the area include extremely high seismicity and the associated risks of sea floor displacement due to faulting or regional tectonic warping that could generate seismic sea waves. In addition, large areas of the sea floor, particularly near the continental shelf edge, are unstable and subject to gravitational slumping. Additional potential hazards locally are the presence of gas-charged near-surface 
sediments, thick deposits of unconsolidated sediment with low bearing strength, and large-scale erosion and deposition of sediment due to strong bottom currents.

\section{INTRODUCTION}

This report outlines the status of knowledge concerning petroleum potential and possible earthquake-related hazards in the Gulf of Alaska

"Tertiary Province (GATP). It amplifies on an Open-File Report (Plafker and others, 1975) that was prepared prior to selection of tracts to be leased for petroleum exploration on the Outer Continental Shelf (OCS) which occurred in April 1976 (OCS Sale \#39). The present report summarizes the earlier work and emphasizes new data that have become available since the pre-nomination report was prepared in December 1975.

The sections of this report on stratigraphy, structure, and petroleum potential were prepared by Plafker and Bruns except for the section on quantitative estimates of petroleum resources which is by Scott. The sections on geologic hazards dealing with seismic history, faulting and warping, tsunamis, and earthquake recurrence and seismic gaps are largely by Plafker with contributions by Carlson and Molnia. The sections on hazards related to soft sediment, gas-charged sediment, gravitational movements, etc., were prepared by Molnia for the Yakutat shelf and by Carlson for the Yakataga and Middleton shelves. Kahler and Wilson authored the section on technology for exploration.

\section{Available Data}

Data acquired since the previous pre-nomination report on the GATP OCS was written (Plafker and others, 1975) have significantly increased knowledge of the resource potential and geologic hazards of this part 
of the OCS. These data include approximately $2,000 \mathrm{mi}(3,200 \mathrm{~km})$ of multichannel seismic lines and five reversed refraction lines acquired in 1975 that have since been processed and interpreted. An additional $800 \mathrm{mi}(1,300 \mathrm{~km})$ of CDP profiles were acquired in 1977 which are only partly processed. During 1977 a program of sampling bedrock outcrops along the continental slope by dredging was undertaken which provided significant control for interpreting seismic profiles at the seaward margin of the Tertiary basin. High resolution seismic profiles and numerous bottom samples of unconsolidated materials were collected during cruises in 1975, 1976, and 1977 for evaluation of geologic hazards on the OCS.

\section{Physiography}

The OCS portion of the GATP covers about $20,000 \mathrm{mi}^{2}\left(52,000 \mathrm{~km}^{2}\right)$ to a water depth of $3,280 \mathrm{ft}(1,000 \mathrm{~m})$. Within this province the area of sea floor above specified depth ranges is approximately as follows:

\begin{tabular}{lcccc} 
Depth & \multicolumn{3}{c}{ Area } \\
$0-650 \mathrm{ft}$ & $0-200 \mathrm{~m}$ & $14,320 \mathrm{mi}^{2}$ & $37,135 \mathrm{~km}^{2}$ & $9.1 \times 10^{6}$ acres \\
$650-3,280 \mathrm{ft}$ & $200-1,000 \mathrm{~m}$ & $5,900 \mathrm{mi}^{2}$ & $15,320 \mathrm{~km}^{2}$ & $3.8 \times 10^{6}$ acres \\
& Total & $20,220 \mathrm{mi}^{2}$ & $54,455 \mathrm{~km}^{2}$ & $12.9 \times 10^{6}$ acres
\end{tabular}

The names of important physiographic and geographic features on the OCS and adjacent land area are given on figure 1 . The width of the continental shelf ranges from as little as $8 \mathrm{mi}(13 \mathrm{~km})$ at the eastern end of the area to $65 \mathrm{mi}(105 \mathrm{~km})$ in the west. A relatively smooth and steep continental slope descends to a gentle continental rise at water depths of 6,600 to $13,200 \mathrm{ft}(2,000$ to $4,000 \mathrm{~m})$ to the east of Kayak Island. West of Kayak Island the slope makes up the inner wall of the 
eastern Aleutian Trench, which has floor depths in excess of $14,800 \mathrm{ft}$ $(4,500 \mathrm{~m}$ ) (von Huene and Shor, 1969). The portion of the slope adjacent to the trench is wider, and is considerably more irregular in topography than the segment of slope to the east of the end of the Aleutian Trench. In general, the topography of the shelf is gently undulating except where it is broken by six major submarine valleys and a number of smaller ones. Topographically low and high areas on the shelf tend to reflect Quaternary structural features. The most prominent named shoal areas are Fairweather Ground, Middleton Platform, and Tarr Bank.

As defined herein, the GATP includes all Tertiary rocks along the mainland·coast in the eastern Gulf of Alaska and their presumed offshore extensions, extending $620 \mathrm{mi}(1,000 \mathrm{~km})$ from Cross sound on the east to the Amatuli Trough on the west (fig. 1). Following previously established usage (Miller and others, 1959; Plafker, 1971) the onshore part of this province is further subdivided into six districts for convenience of discussion. From west to east these are the Prince William Sound, Katalla, Yakataga, Malaspina, Yakutat, and Lituya districts (fig. 1).

For convenience of discussion of the continental shelf in the GATP, we have subdivided the ocs into four geologically or physiographically distinctive areas. From east to west they are the Yakutat shelf between Cross Sound and the Icy Bay area, the Yakataga shelf between Icy and Kayak Island, the Middleton shelf between Kayak Island and Hinchinbrook Sea Valley, and the Seward shelf between Hinchinbrook Sea Valley and Amatuli Trough. 
GEOLOGIC SUMMARY

Geologically, the GATP is a compound continental margin basin made up almost entirely of terrigenous clastic rocks that are intercalated with subordinate mafic volcanic and volcaniclastic rocks and with minor coal. The bedded rocks of the onshore Gulf of Alaska Tertiary Province, with a cumulative post-Paleocene thickness of at least 50,000 ft $(15,000$ m), include both marine and nonmarine units. General geologic features of the Tertiary basin and its margins are shown by figure 2 . Figure 3 is a correlation chart of stratigraphic units in the basin; the approximate thickness and inferred correlations of selected surface and well sections are shown in figure 4. Data on the stratigraphy and onshore structure relevant to petroleum potential have been summarized by Plafker (1971) and Plafker and others (1975) and will not be repeated here.

The Tertiary rocks are bordered on the north, and are underlain in the eastern part of the basin, by bedded rocks of Cretaceous and older age (fig. 2). These rocks are highly deformed, locally metamorphosed, and are commonly intruded by igneous plutons. The pre-Tertiary rocks are considered to have no potential for petroleum.

Geologic History

The southern margin of Alaska began to assume its present form in about mid-Cretaceous time by assembly of several northward-moving microplates, including the Alexander Terrane and Wrangellia, against a Precambrian to middle Paleozoic nuclear Alaska. During the Campanian and Maestrichtian, a volcanic arc developed along the northwestwardtrending continental margin as a result of relative northeastward underthrusting by Pacific oceanic crust. During the existence of this arc, 
a volcanogenic flysch and melange sequence with subordinate oceanic basalt (Chugach Terrane) was accreted along the continental margin northwest of Chatham strait in a continuous belt up to $62 \mathrm{mi}(100 \mathrm{~km})$ wide, a subparallel volcanoplutonic arc was developed on continental crust to the north of the accretionary belt, and shelf deposits were laid down in an arctrench gap basin.

A major redistribution of plate motions at the beginning of the Tertiary resulted in northeastward movement of Pacific oceanic crust relative to the Alaska continental margin. Also about this time, roughly $95^{\circ}$ of counterclockwise oroclinal bending of western Alaska occurred about a main axis through Prince william Sound and a secondary axis through Yakutat Bay. As a consequence of these relative plate movements, ensimatic deep sea fan deposits and associated oceanic tholeiitic basalts of late Paleocene and early Eocene (?) age that comprise the Orca Group and related rocks were accreted along the western limb of the oroclinal bend to form a belt with an exposed width of $68 \mathrm{mi}(110 \mathrm{~km})$ that probably also underlies much or all of the continental shelf west of Kayak Island. Because they are complexly deformed, mildly metamorphosed, and locally intruded by granitic plutons these deep sea rocks are considered to have no petroleum potential.

During middle to late Eocene time, deposition at the continental margin became regressive, with development of a thick coal-bearing lagoon, barrier beach, and delta complex. The complex was supplied largely by sediment derived from erosion of the now uplifted cretaceous to early Tertiary accretionary sequences and from granitic plutons emplaced in them. Bedded rock units include the Kushtaka, Kulthieth, and Tokun Formations. 
Transgression occurred during Oligocene and early Miocene time, and predominantly shaly sediment, in part organic-rich and intercalated with water-laid alkali basaltic tuff, breccia, and pillow lava, accumulated. These bedded rocks comprise the Katalla, Poul Creek, and Cenotaph Formations.

The present sedimentary and tectonic regime results from movement of the Pacific Plate northwestward relative to the Alaskan continental margin since the early Miocene. Due to this motion, the Aleutian Trench and volcanic arc developed by underthrusting of the continental margin in the northern and western Gulf of Alaska whereas dextral transform faulting prevailed along the eastern margin of Gulf of Alaska. From the midale Miocene to the present, an enomous thickness of clastic sediment comprising the Yakataga, Redwood, and Topsy Formations, and including much glacially-derived material, was rapidly deposited in a predominantly shallow shelf environment. Concurrently, deep-water sediments were being deposited in slope basins and offscraped against the continental margin at the inner wall of the Aleutian Trench. Simultaneous deformation related to plate convergence and gravitational sliding has resulted in complex folding and thrust faulting of the bedded Neogene rocks throughout much of the Gulf of Alaska, together with large-scale strike-slip faulting in the eastern Gulf of Alaska.

\section{PETROLEUM GEOLOGY}

\section{Exploration History}

Abundant oil and gas seeps in the Katalla, Yakataga and Malaspina districts (fig. 2) first directed attention to the petroleum possibilities of the onshore northern Gulf of Alaska. One minor field at Katalla was 
discovered and produced between 1902 and 1933, 25 wells and core holes were drilled and abandoned onshore between 1954 and 1963, and one offshore well was drilled and abandoned in 1969 on state lands near Middleton Island. Available information on these wells is summarized in Plafker and others (1975), and Rau and others (1977). A stratigraphic test well was drilled on the ocs southwest of Cape Yakataga in 1975 (table 1 and fig. 6) but was terminated in Pleistocene strata at a depth of 5,150 ft $(1,570 \mathrm{~m})$ when arilling and weather problems significantly reduced the chances of penetrating potential objective horizons (Bolm and others, 1976). The first federal OCS oil and gas lease sale in Alaska (OCS Sale No. 39) was held for the area between Icy Bay and Rayak Island in April 1976 (fig. 6). Since the sale, nine offshore wildcat wells have been drilled and abandoned with no discoveries of commercial oil or gas and one well was still drilling as of June 1, 1978. Geologic information from these wells is proprietary; their locations are shown on figure 6 and available drilling information is summarized in table $I$.

\section{Source Rocks}

Data on potential source rocks and surface indications of petroleum were detailed by Plafker (1971) and Plafker and others (1975). On the basis of the stratigraphic units in which most of the oil seeps and other indications of petroleum were found, a probable source in the middle part of the Tertiary sequence is indicated. Bedded rocks of early Tertiary age are believed to have little petroleum potential because of their characteristically high degree of induration. The Orca Group and preTertiary rocks in this region are effective basement for petroleum. 


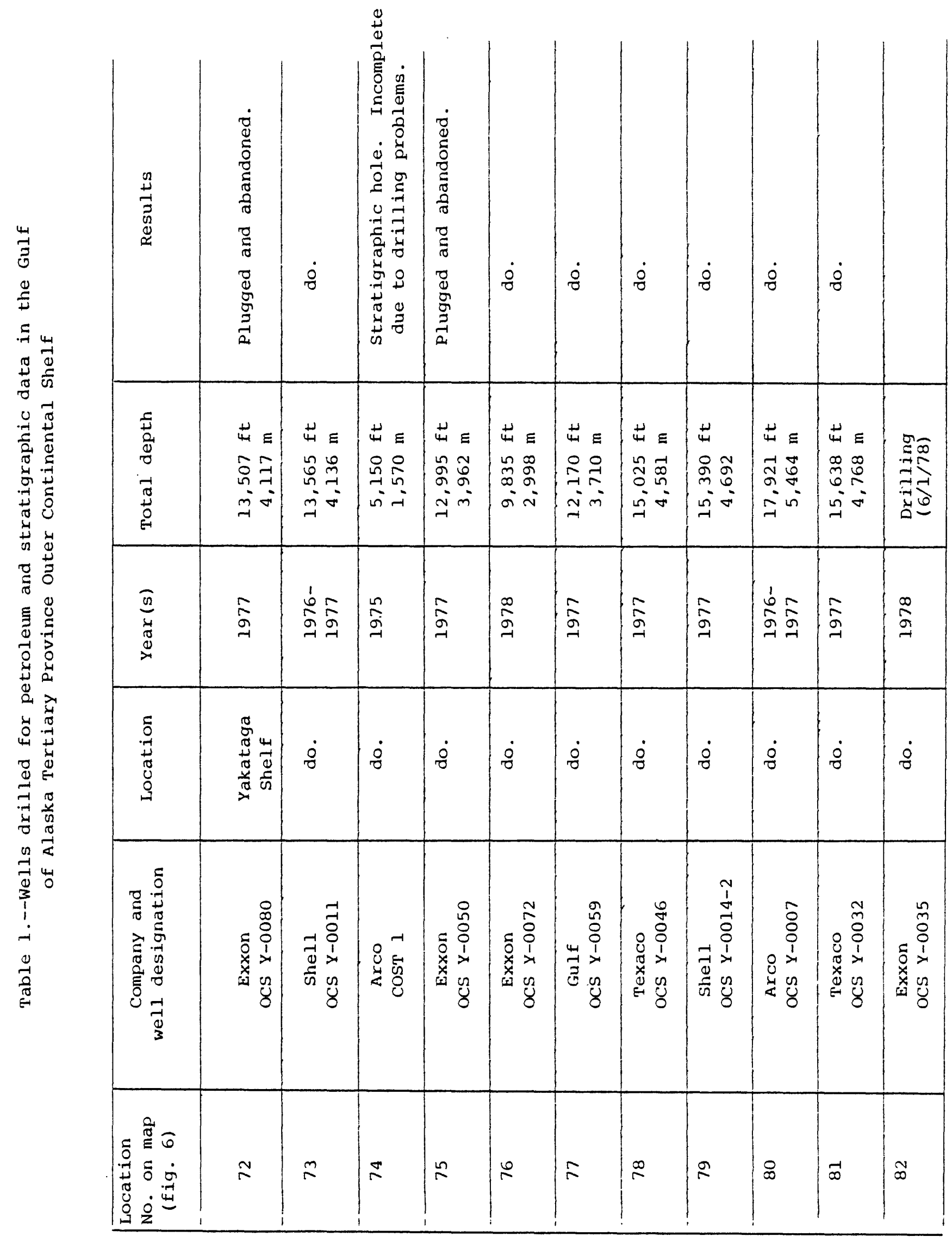


The offshore distribution of the organic-rich facies is unknown. It does not occur in the Middleton Island well. Samples of middle Tertiary age that were dredged from the continental slope adjacent to the Yakutat shelf have relatively high organic carbon contents but are not sufficiently mature to have produced liquid hydrocarbons (Plafker and others, 1978a). However, the rocks may be buried deeply enough to have generated petroleum in the large structural low that underlies most of the Yakutat shelf north of the Fairweather Ground. Offshore seepages of oil and gas have not been reported despite heavy commercial fishing over much of the continental shelf and despite the known occurrence of numerous geologically young faults in the subbottom sequence along which petroleum could leak to the sea floor if it were present.

\section{Reservoirs}

Sandstones in the GATP Tertiary sequence are the only likely potential reservoir rocks with primary porosity and permeability. The reservoir characteristics of the Tertiary sandstones from the outcrop and wells have been presented by Winkler and others (1976) and by Plafker and others (1975); data on dredge haul samples are given by Plafker and others (1978a). Outcrop and dredge haul samples from the continental slope are compositionally and texturally immature. Even the best-sorted sandstones appear to have poor reservoir characteristics because they are greatly compacted and tightly cemented with authigenic silica, zeolites, and carbonates.

Better sorted and less indurated sandstone is present locally in the middle and upper Tertiary sequences, but most of the outcrop samples also have fairly low porosity and permeability, mainly because of a finegrained matrix of rock flour and primary and authigenic phyllosilicates. 
Most of the outcropping Yakataga sandstone that has been examined microscopically shows interstices effectively plugged by deformed detrital lithic fragments that comprise an average of 23 percent of the sand grains. Locally, however, selected strandline sandstones have been found in outcrops of the uppermost Yakataga Formation of the eastern Yakataga district that have porosities over 20 percent and permeabilities of a few hundred millidarcies (Anon., 1976).

The source of the Neogene clastic sediments in the basin was primarily on the north and northeast. Consequently, average grain size and sorting of the sandstones normally would tend to decrease offshore with a concomitant reduction in porosity and permeability. It is conceivable, however, that sorted sands in large quantity could have been transported well out into the basin by turbidity currents, or that unsorted sands may have been reworked along the flanks of structural highs that might have been elevated to or near sea level sometime after deposition within the basin.

\section{Structural Traps}

\section{Introduction}

Multichannel seismic reflection data indicate that the continental shelf and slope are geologically complex with markediy different structural styles in the Yakutat, Yakataga, Middleton, and Seward shelves. Figures 5, 6, and 7 show the important structural features in the portions of the GATP OCS where adequate geophysical data are available. Structural contours are based on available multichannel seismic data; depth conversion is developed from wells and offshore seismic velocity data. Previously published interpretations of single channel reflection seismic data and refraction surveys include Bruns and Plafker $(1975,1976)$ and Bayer and others (1977). 


\section{Yakutat Shelf}

The Yakutat shelf (fig. 5) is bounded on the north and east by deformed Tertiary strata and the Fairweather fault, on the south by the continental slope, and on the west by a broad zone of geologically young faults and folds termed the Pamplona zone (fig. 6). The structural configuration at a horizon believed to be near the base of the late Cenozoic Yakataga Formation is shown by structure contours on figure 5 . The contours are controlled by regional multichannel seismic lines, dredge data, and onshore wells.

A large shelf-edge high, Fairweather Ground, roughly parallels the coast between Cross Sound Canyon and Alsek Canyon. Dredge hauls indicate that the core of the high and much of the continental slope off Fairweather Ground consists of pre-Tertiary rocks typical of the Yakutat Group on the adjacent mainland. Sedimentary rocks of late Cenozoic age similar to the Yakataga Formation occur in isolated basins on the pre-Tertiary basement in the vicinity of Fairweather Ground (Plafker and others, 1978a). To the northeast sedimentary rocks lap onto the high from a broad basin with the axis near the coast and with a thickness of at least $10,000 \mathrm{ft}(3,000 \mathrm{~m})$.

Between Alsek Canyon and the Pamplona zone, the Tertiary section thickens markedly, and includes rocks ranging in age from late Eocene and possibly older through late Oligocene (Plafker and others, 1978a). This older Tertiary sequence, roughly $10,000 \mathrm{ft}(3,000 \mathrm{~m})$ thick, overlies probable Cretaceous basement. Seismic reflection data indicate that the early Tertiary strata comprise a wedge that dips and thins toward the coast. This older Tertiary sequence is overlain by a gently dipping younger sequence at least $20,000 \mathrm{ft}(6,000 \mathrm{~m}$ ) thick near the coast (fig. 5 
and section A, fig. 8). The axis of the basin is near the coast, with the suggestion of a mid-basin arch. The late Cenozoic fill is relatively undeformed, and is gently dipping or flat lying with no major structural features. The presence of an early Tertiary high is suggested by section A of figure 8 (line 403), but the trend of the high and closure along strike are not confirmed by available processed data.

\section{Yakataga Shelf}

Between the Pamplona zone that extends southwest of Icy Bay and Kayak Island, numerous anticlinal folds are present on the shelf that have been the target of current petroleum exploration efforts (fig. 6, table 1). The easternmost folds of the Pamplona zone define the boundary between the relatively undeformed Yakutat block and the Yakataga shelf (Plafker and others, 1978b). The Yakataga shelf is bounded on the north by the folded and faulted onshore Tertiary section, on the west by Kayak Island and on the south by the base of the continental slope. Structure contours on a horizon in the lower Yakataga Formation (fig. 6) show the configuration of late Cenozoic sedimentary rocks of the Yakataga shelf. The contours are controlled by a regional multichannel seismic network and by extrapolated ties to onshore wells. The deeper structure is not known due to a general lack of penetration of acoustic energy below the Yakataga Formation, but may be more complex than that shown in figure 6 .

Numerous large folds and faults are also present on the continental slope below the $200 \mathrm{~m}$ isobath as indicated in figure 6; analysis of these structures is incomplete and awaits processing of multichannel seismic data acquired during 1977. The structures that cross the continental slope probably reflect primarily latest cenozoic deformation of Yakataga age 
sediments. At least one of these structures that was dredged south of Middleton Island consisted in part of hemipelagic sediments of Pleistocene age (Plafker and others, 1978a).

The anticlines are large, asymmetric, elongate, doubly plunging folds that trend obliquely across the shelf and slope, roughly from northeastsouthwest to east-west. This group also includes the Yakataga and Sullivan anticlines onshore. The shelf structures are commonly bounded on the southeast by northwest-dipping thrust faults, show strong evidence of growth primarily in late Cenozoic time that is still continuing in places, and are generally younger along the southeast and east margins of the area. Width of individual structures ranges from $21 / 2$ to about $6 \mathrm{mi}$ (4 to about $10 \mathrm{~km})$, and closure on the lower Yakataga horizon along strike is present for distances on the order of 9 to $25 \mathrm{mi}$ ( 15 to $40 \mathrm{~km}$ ). Dips on the flanks of the anticlines commonly range between $13-15^{\circ}$ on the landward side and from $5-30^{\circ}$ on the seaward side.

A broad shelf edge high occurs between Kayak Island and the Bering Trough that trends parallel to the coast, has gentle surface dip, and becomes increasingly complex at depth. There is closure on three separate culminations of the high (fig. 6). This structure shows evidence of earlier growth than the other anticlinal folds on the Yakataga shelf; the growth has continued into late cenozoic as shown by the tilted and truncated sediment at or near the surface.

The structural style of the Yakataga shelf is illustrated on figure 8 by sections $B$ and $C$. On section $B$ (line 406), deformation of even the youngest sediment and absence of pronounced growth features indicate recent development of the folds. Section C (line 409) shows the buried structures 
with increasingly younger section being affected by anticlinal folding to the southeast and with gentle doming of younger sediment due to reactivation of movement on the bounding faults.

\section{Middleton Shelf}

Structural style of the Middleton Shelf is characterized by complex, tightly folded and extensively faulted anticlines trending generally east-west and a shelf edge high on which Middleton Island is situated (fig. 7; section D of fig. 8). Structural highs tend to be asymmetric and bounded by major faults on the south. Uplift, folding, and faulting are more extreme in this area than in areas to the east, and the crests of many of the highs appear to have undergone extensive erosion and truncation, exposing complexly deformed rocks at or near the sea floor as well as on land at Kayak and wingham Islands (Plafker, 1974). Structural contours on figure 7 , which are probably on a lower to mid-Yakataga seismic horizon, show the general structural configuration of the shelf. Lack of seismic penetration and steep dips severely limit the interpretation of the geology in this area. Most of these structures appear to be older than those on the Yakataga shelf. The Yakataga Formation is substantially thinner than it is to the east and early to mid-Tertiary strata are locally present relatively near the sea floor.

Northwest of Middleton Island there are several northwest-southeasttrending highs separated by relatively deep basins. These structures show severe deformation and probable faulting on their flanks, and no structure is resolvable within the cores. Middleton Island lies on the northwest flank of a large northeast-trending structure that is bordered on the west by a relatively deep basin. Landward of these structures, in the area 
that includes Tarr Bank, Hinchinbrook Sea Valley, and the Copper River delta, seismic basement appears to be high and the lower Tertiary orca Group may be relatively near the surface.

Seward Shelf

Only three seismic reflection records are available across the shelf between Middleton Island and the Amatuli Trough. These data indicate that the structure is in general similar to the Middleton shelf with locally pronounced uplift, faulting, and generally thinner yakataga sediment than on the Yakataga shelf. The data are insufficient to trace horizons through the area; however, a series of steep reverse faults, some of which reach the surface, are found seaward of a projection of the faults on southern Montague Island that were active during the 1964 earthquake (Plafker, 1967). The seaward edge of the Seward shelf has no near-surface structural high comparable to those that characterize most other parts of the Gulf of Alaska.

Relative Petroleum Potential by Area

General considerations

The critical factor for accumulation of commercial petroleum deposits in the GATP OCS probably is the availability of adequate reservoir sandstone in close association with middle Tertiary petroliferous mudstone and siltstone. The necessary conditions are most likely to be fulfilled along the flanks and over the crests of structural highs that were growing synchronously with middle Tertiary sedimentation. Stratigraphic relations onshore suggest that some anticlines in the Yakataga and Malaspina districts were growing intermittently throughout much of Miocene and probably all of Pliocene time. If comparable or older synchronous highs are 
present on the continental shelf, and were at or near sea level for sufficient periods of time, they could have been the loci for accumulation of winnowed sandstone wedges with better sorting than that of coeval sands laid down in the deeper water of the intervening area. Furthermore, early accumulation of hydrocarbons in such winnowed sandstone bodies could have inhibited the type of secondary cementation that in the outcrop has made the sandstone generally unsuitable for commercial reservoirs.

Yakutat Shelf.--Structural traps are present locally at Fairweather Ground in the upper Yakataga Formation and on an early Tertiary high in the center of the basin. In addition, extensive stratigraphic traps may be present at unconformities along the flanks of the Fairweather Ground structure. Because the Fairweather Ground high is an enormous structure with a potential for major stratigraphic traps along its flanks and a large deeply buried petroleum source in the structural low that borders it to the northeast, it should be an especially interesting target for petroleum exploration.

Yakataga Shelf.--Numerous large, open structures with demonstrated closures are present under the shelf and continental slope. In addition, petroleum seeps occur on adjacent onshore structures, some of which trend into the offshore. However, recent drilling activity which tested the largest offshore structures has failed to encounter commercial hydrocarbons. Dredge samples together with geophysical data indicate that the slope structures are young and have negligible potential for petroleum. Although not yet fully tested by drilling, the potential for the occurrence of petroleum in commercial quantities can be considered no better than poor to fair and the potential for discovering giant oil fields is considered to be poor. 
Middleton Shelf.--Some structures are large but major downgrading factors in this area are the structural complexity and lack of good source rocks and sandstone reservoirs in the Middleton Island well. Potential middle Tertiary target horizons may be shallower and therefore more easily drillable than under the Yakataga shelf, but may also be breached by erosion in some of the highs. Overall potential is considered to be poor. Seward Shelf.--Data are insufficient to evaluate the potential of this area, but in general it appears to be similar to the Middleton shelf and may be considered to have poor petroleum potential.

\section{QUANTITATIVE ESTIMATES OF PETROLEUM RESOURCES}

Estimates were made of the potential oil and gas resources of the northern Gulf of Alaska Tertiary Province as part of a project for the total United States, onshore and offshore. The results of the study were published as U. S. Geological Survey Circular 725, Geologic Estimates of Undiscovered Recoverable Oil and Gas Resources of the United States. The estimates given in the report were derived by a series of geological and volumetric-yield analog procedures followed by the application of subjective probability techniques to get:

1 - A low resource estimate with a 95 percent probability that there is at least that amount.

2 - A high resource estimate with a 5 percent probability that there is at least that amount.

3 - A modal estimate of highest probability of occurrence. These values are computerized and processed as probability distributions by lognormal curves (fig. 9). 
There is a real possibility that there may not be a commercial occurrence of oil or gas in a frontier area such as the Gulf of Alaska; consequently, a marginal probability is assigned. In this case, the probability of no commercial oil or gas is estimated to be 30 percent; thus estimates of the quantities of resource to be found at the 95 percent probability level are "o".

The estimates of the amounts of undiscovered recoverable oil and gas that may be present in the continental shelf of the northern Gulf of Alaska are:

$\begin{array}{lcccc} & 95 \text { percent } & 50 \text { percent } & 5 \text { percent } & \text { Statisti- } \\ & \frac{\text { Probability }}{\text { OII - billions }} & 0 & \frac{\text { Probability }}{\text { Probability }} & \text { cal Mean } \\ \text { of barrels. } & 0 & 0.5 & 4.4 & 1.4 \\ \text { GAS - trillions } & 0 & 2.0 & 13.0 & 5.0 \\ \text { of cubic feet. } & & & & \end{array}$

The figures for the 95 percent and 5 percent probabilities were derived by the procedures described in Circular 725 . The 50 percent probability figure is taken from the lognormal curve of probabilities.

Certain qualifications have to be made regarding these estimates. Several tests have been drilled in the central part of the Gulf of Alaska. The results of these tests are not available at this time but they are not believed to be very encouraging. However, because of the large size of the area, the small number of tests and the lack of specific information on the tests, no changes have been made in the estimates for use in this report. 
GEOLOGIC HAZARDS

General statement

The geology and topography of the Gulf of Alaska Tertiary province record an extremely high level of tectonic activity during the late Cenozoic, and the earthquake history of the region clearly demonstrates that tectonism continues undiminished to the present. Judging from past experience, major earthquakes that could pose serious potential hazards to installations on the continental shelf or along the Gulf of Alaska. coast may occur in the future. The hazard may be either direct by ground shaking, fault displacement, and tectonic warping, or indirect through ground failure or generation of tsunami waves.

Other potential nonseismic geologic hazards are the possibilities of encountering overpressurized gas pockets at shallow depth during exploratory drilling and potential instability of unconsolidated deposits on which structures may be sited.

\section{Seismic History}

The GATP is the most seismically active region in the United States apart from the Aleutian Islands. The earthquake history has been reviewed by R. A. Page in Plafker and others (1975) and the larger earthquake epicenters and faults are plotted on figure 10. Five major earthquakes, equal to or larger than magnitude 7.8 , have occurred in the province during the last 75 years. The most recent of these shocks--1964 Alaska earthquake (magnitude 8.5)--is one of the largest earthquakes ever recorded. Epicentral locations for these earthquakes, and many smaller ones, are shown on figure 10. 


\section{Faulting and Warping}

The larger known coastal late Cenozoic faults or systems of faults around the margin of the Gulf of Alaska are shown on figure 10. Fault displacements and large-scale vertical movements of the land relative to sea level are known to have occurred during three great earthquakes in the Gulf of Alaska Tertiary Province. The 1899 Yakutat Bay earthquake was accompanied by a complex pattern of tectonic warping and tilting over an area of about $580 \mathrm{mi}^{2}\left(1,500 \mathrm{~km}^{2}\right)$ centered on Yakutat Bay (Tarr and Martin, 1912; Thatcher and Plafker, 1977). The 1958 Lituya earthquake was accompanied by right-lateral slip of up to $21 \mathrm{ft}(7 \mathrm{~m})$ on the Fairweather fault (Tocher, 1960). Marine data indicate that the active fault rupture extends offshore to the southeast of Palma Bay (fig. 11). The most recent and largest earthquake to affect the region, the 1964 Alaska event, is believed to have been generated by dip-slip displacement of $66 \mathrm{ft}(20 \mathrm{~m})$ or more on a segment of the Aleutian Arc megathrust system at least $500 \mathrm{mi}$ $(800 \mathrm{~km})$ long (Plafker, 1969). Significant tectonic deformation affected a minimum area of $77,000 \mathrm{mi}^{2}\left(200,000 \mathrm{~km}^{2}\right)$ and two subsidiary reverse faults with up to $26 \mathrm{ft}(7.9 \mathrm{~m})$ dip slip broke the surface on Montague Island. Marine data (Plafker, 1967; Carlson and Molnia, 1978) indicate they extended offshore onto the continental shelf to the southwest (figs. 10 and 13).

Many subbottom faults have been identified on high-resolution seismic profiles (figs. 11-13). Few of the faults mapped on the continental shelf of the GATP appear unequivocally to offset Holocene sediments. Conceivably, lack of topographic offset of the Holocene sediment may be due to either the extremely unconsolidated nature of surface sediment resulting in 
self-annealing of sea-floor ruptures, or the rapid rate of sediment accumulation which can be as much as $0.2-0.6$ in/yr (5-15 mm/yr) (Carlson and others, 1977). However, faults with Holocene vertical displacement should show up in the subbottom high-resolution profiles. In view of the onshore record of active deformation and the distribution of shallow focus earthquake epicenters on the continental shelf, the likelihood of future displacement of the sea floor is a distinct probability.

\section{Tsunamis}

Most major earthquakes that involve vertical tectonic displacements of the seabed are followed by tsunamis (seismic sea waves or "tidal" waves). The earthquake of March 27, 1964, generated one of the larger seismic sea-wave trains of modern times (Plafker, 1969). Future earthquakes involving tectonic deformation of the continental shelf in the eastern Gulf of Alaska may be expected to be accompanied by tsunami waves. Their damage potential will depend to a large degree upon the amount and rate of deformation, the stage of tide, and the effect of bottom configuration on amplification and focusing of the waves. A tsunami comparable to the one that accompanied the 1964 earthquake is probably a reasonable maximum that should be anticipated.

There is no historic record of inundation of the eastern Gulf of Alaska coast by tsunami waves from distant earthquakes.

\section{Earthquake Recurrence and Seismic Gaps}

Studies of displaced shorelines (Plafker, 1972) and historic seismicity (Sykes, 1971) independently identify portions of the GATP shelf and slope extending from the vicinity of Icy Bay westward to the Middleton Island area as a region where one or more major earthquakes are highly probable. 
Data on which this conclusion is based have been summarized by Plafker and others (1975) and by Page (1974).

\section{Submarine Slumps and Slides}

Large submarine sediment slides and slumps occur on the continental shelf and upper slope in the GATP. These submarine slope failures are characterized by being larger and occurring on much flatter slopes than subaerial slides (Hampton and others, 1978). Areas of submarine mass movement are indicated on figures 11,12 , and 13. Some of them extend for more than $56 \mathrm{mi}(90 \mathrm{~km})$ along strike with areas of up to $417 \mathrm{mi}^{2}$ $\left(1,080 \mathrm{~km}^{2}\right)$ and may show offsets on headwall scarps of $16-66 \mathrm{ft}(5-20 \mathrm{~m})$. In addition, indications of slumping are apparent on many of the seismic lines that crossed the shelf-slope break. Although the track line spacing is not dense enough to permit delineation of discrete slump or slide masses, spot locations of profiles showing slumps are recorded on the figures. These features have been discussed in considerable detail by Carlson and Molnia (1977), Carlson and others (1977), Hampton and others (1978), Molnia and others (1977), and Molnia (1976).

In addition to areas in the ocs where slump or slide structures are observed on the seismic profiles, areas have been mapped that appear to be potential slide or slump zones (figs. 11-13). Delineation of these potentially hazardous areas was made on the basis of thickness of Holocene sediment and relative slope steepness. Slump or slide features were not prominent on the profiles; however, because the sediment is in excess of $82 \mathrm{ft}$ thick $(>25 \mathrm{~m})$ and slopes are more than $1.8^{\circ}$ there is a possibility of ground failure in these areas if a large earthquake generates longcontinued high ground accelerations or if large tsunamis or storm waves discupt the sea floor. 
Gas in Sediments

Some nearshore areas may have gas present in the near surface that could result in low bearing strength and unstable sediments due to excessive pore pressures. In addition, gas-rich sediments could present a hazard if penetrated by drilling.

Discontinuous near-surface reflectors along the east side of Kayak Island that have been identified as indicative of gas-charged sediment by Carlson and Molnia (1977) contain high concentrations of methane (Kvenvolden and others, 1977). Similar reflectors east of Dry Bay and Situk and Dangerous Rivers (fig. 11) are believed to represent gas-charged sediment but samples have not yet been collected to determine their gas content.

\section{Sediment Thickness}

Many nearshore areas have unconsolidated Holocene sediment more than $330 \mathrm{ft}(100 \mathrm{~m})$ thick that, because of their low strength, could present a problem for siting structures (Carlson and Molnia, 1975). Portions of the Alsek and Yakutat Sea Valleys have over $490 \mathrm{ft}(150 \mathrm{~m})$ of unconsolidated sediment and many areas on the shelf show evidence of glacial channels filled by as much as 390-460 ft (120-140 m) of Holocene sediment (Molnia and others, 1978). No data on water content or shear strength have been collected. However, grain size and clay mineralogy of this area are similar to that west of Yakutat where low bearing and shear strengths have been found.

\section{Bedforms}

Bedforms are indicative of moving sediment and strong bottom currents. Two areas between Yakutat and Dry Bay appear to have regular bedforms 
within $3 \mathrm{mi}(5 \mathrm{~km})$ of shore (Molnia and others, 1978). The largest group, south of the Situk River, has a field with dunelike forms almost a kilometer in length with heights of about $33 \mathrm{ft}(10 \mathrm{~m})$. The other area southeast of Ocean Cape has much smaller features. Both areas need further investigation if structures are to be sited in them.

\section{Other Hazards}

Other types of geologic hazards which need to be considered in the GATP OCS for siting of structures include: 1) rapid marine sedimentation, such as at Icy Bay (Molnia, 1977a); 2) the occurrence of submarine glacial moraines and buried ice such as at the mouths of Yakutat Bay and Icy Bay, offshore of Bering and Malaspina Glaciers and Cross Sound, and at Lituya Bay (Molnia, 1976); 3) local high rates of beach erosion and deposition (Molnia, 1977a, 1977b); and 4) onshore glacier lake breakout (Post and Mayo, 1971), and landslide-generated waves in bays (Tarr and Martin, 1912; Miller, 1960).

\section{TECHNOLOGY FOR EXPLORATION}

The developing technology for offshore oil and gas exploration and development has permitted a progression from activity in shallow water and in moderate climates to work in deeper water and more hostile environments. The industry has greatly increased its offshore operating capabilities in recent years. In 1977, an exploratory well was drilled off Surinam in $3,950 \mathrm{ft}(1,200 \mathrm{~m})$ of water; a well spudded off the Congo in early 1978 in $4,348 \mathrm{ft}(1,325 \mathrm{~m})$ of water; and a well is planned off Newfoundland in 1979 in 5,300 ft $(1,615 \mathrm{~m})$ of water. A steel production platform was placed offshore in California in $850 \mathrm{ft}(260 \mathrm{~m})$ of water in 1976, and another is presently being placed offshore Louisiana in 1,015 ft 
$(310 \mathrm{~m})$ of water. Developments in pipelines, offshore floating or sunken storage, offshore support or accommodation platforms, offshore field processing, diver and diverless maintenance equipment, quick-disconnect and reconnect systems, seafloor gathering systems, safety facilities, rig locator instrumentation, on-platform waste recycling equipment, cold strength steels, communications between platforms and shore bases, selfpropelled semisubmersibles --- all of this technology and more is following the route of improvements in exploration equipment which will be necessary to match any discoveries being made in the deeper and more harsh ocean environments.

\section{Drill Rig Availability}

At year-end in 1977, the world's fleet of mobile drilling rigs available for use was approaching 400, with 26 more under construction. Day rates have varied with the supply/demand balance, and it should be noted that the day rates for heavy-duty semisubmersibles such as those used in the Gulf of Alaska are from two to four times higher than the present world average rate. There appears to be no limitation in the immediate future for drilling unit availability, although temporary spot shortages by type of equipment and by geographic area may occasionally show up.

\section{Comparison with North Sea Development}

The development of the North Sea oil and gas province may provide a rough guide to the technological outlook for the Gulf of Alaska. Since 1964, more than 1,400 holes have been drilled, of which one-third are producers. The province is generally becoming mature, but active exploration work is continuing northwest of the Shetland Islands in water over 
$700 \mathrm{ft}(213 \mathrm{~m})$ deep, and north of $60^{\circ} \mathrm{N}$. latitude. The most northerly discovery is the Magnus oil field, at $61.6^{\circ} \mathrm{N}$. latitude and in $614 \mathrm{ft}$ $(187 \mathrm{~m})$ of water; it was discovered in mid-1974, and plans are now being made for placing its estimated 450 million barrels of recoverable oil on production.

Immediately southeast of Magnus, the Thistle field drilling and production platform, built of steel, was installed in 1976 in $530 \mathrm{ft}$ (160 m) of water. Weighing a total of more than 50,000 tons, it is designed to handle a maximum of 280,000 barrels per day of oil, plus reinjecting the gas and injecting water for reservoir pressure maintenance. The oil is to be produced into an underwater 36 in $(91 \mathrm{~cm})$ pipeline to a terminal about $130 \mathrm{mi}(210 \mathrm{~km})$ distant, on the Shetland Islands. The platform was designed to withstand a once-in-100-year storm with $93.5 \mathrm{ft}(28.5 \mathrm{~m})$ waves, $152 \mathrm{mph}(245 \mathrm{kph})$ wind gusts, and one-minute sustained winds of $126 \mathrm{mph}$ $(203 \mathrm{kph})$. It has 60 well slots and the well depths average 12-13,000 ft $(3.7-4,000 \mathrm{~m})$, with a range of $9,000 \mathrm{ft}(274 \mathrm{~m})$ to $17,000 \mathrm{ft}(5,182 \mathrm{~m})$ depending on drillhole deviation and reservoir structure. Estimated recoverable reserves are 550 million barrels. One pipeline and one terminal will service several fields clustered near Thistle, thus improving the overall economics. Time has been a problem; Thistle was discovered in 1973 and the terminal's crude-stabilization equipment will not be operable until well into 1980 . This field has been discussed in some detail here because, with relatively minor variations, it might compare to any prolific discovery situation in the Gulf of Alaska, particularly as regards wind, waves, latitude, cold weather, water depths, and distance from supporting shore facilities. 
OCS Drilling Experience

The experience gained to date in the Gulf of Alaska confirms prior predictions that exploratory operations will be influenced by harsh weather and severe sea conditions. Nine wells have been drilled in the time period September 1976 through March 1978 (table 1). All were drilled with semisubmersibles and six of the locations were drilled either partly or entirely in winter weather. Delays caused by weather were nominal. Water depths for the nine locations range from $246 \mathrm{ft}(75 \mathrm{~m})$ to $873 \mathrm{ft}$ $(267 \mathrm{~m})$ and drilling times plus testing time ranged from 65 days to 220 days. The deepest well, which was $17,921 \mathrm{ft}(5,462 \mathrm{~m})$ cost roughly $\$ 23$ million, and average well costs were in the vicinity of $\$ 15$ million.

\section{FINANCES}

Oil industry capital requirements for Gulf of Alaska leasing, exploring, producing and transporting to market must be measured against the general overall financial situation of U. S. - based companies, and in particular, their ability to borrow money as needed. Major banks in this country have indicated that the maximum safe ration of debt to total capitalization for oil companies is in the range of 25 percent to 40 percent. Present indebtedness reportedly is between 25 percent and 30 percent, and is rising at a rate which may bring it to 40 percent in 1985-90. This suggests that while the industry and its better-managed component companies may not yet be at serious debt levels, and thus have some flexibility at this time in choosing to operate in the Gulf of Alaska, the trend of debt loan is not good and cannot be indefinitely maintained. 


\section{REFERENCES CITED}

Anonymous, 1976, A stratigraphic study of the Gulf of Alaska Tertiary Province, northern Gulf of Alaska area: State of Alaska Open-file Report 93, $24 \mathrm{p}$.

Bolm, J. G., Chmelik, F. B., Stewart, G. H., Turner, R. F., Waetjen, H. H., and Wills, J. C., 1976, Geological and operational summary, Alaska stratigraphic test OCS $75-60$, No. 1, northern Gulf of Alaska: U.S. Geol. Survey Open-file Report, 40 p.

Bruns, T. R., and Plafker, George, 1975, Preliminary structural map of part of the offshore Gulf of Alaska Tertiary Province: U.S. Geol. Survey Open-file Map 75-508. 1976, Structural elements of the offshore Gulf of Alaska Tertiary Province [abs.]: Program and abstracts of Pacific section AAPG Mtg., Apr. 21-24, 1976, p. 43.

Carlson, P. R., and Molnia, B. F., 1975, Preliminary isopach map of Holocene sediments, northern Gulf of Alaska: U.S. Geol. Survey Openfile Report 75-507. 1977, Submarine faults and slides on the continental shelf, northern Gulf of Alaska, Marine Geotechnology, v. 2, Marine Slope Stability. 1978, Minisparker profiles and sedimentologic data from the R/V ACONA cruise (4/76), Gulf of Alaska and Prince William Sound: U.S. Geol. Survey Open-file Report 78-381.

Carlson, P. R., Molnia, B. F., Kittelson, S. C., and Hampton, J. C., Jr., 1977, Map of distribution of bottom sediments on the continental shelf, northern Gulf of Alaska: U.S. Geol. Survey MF-876. 
Hampton, M. A., Bouma, A. H., Sangrey, D. A., Carlson, P. R., Molnia, B. F., and Clukey, E. C., 1978, Quantitative study of slope instability in the Gulf of Alaska: loth Offshore Technology Conference, Houston, Texas, Proceedings, v. 4, p. 2307-2318.

Kvenvolden, K. A., Redden, G. D., and Carlson, P. R., 1977, Hydrocarbon gases in sediments of the eastern Gulf of Alaska: Am. Assoc. Petroleum Geologists Bull., v. 61, p. 806.

Miller, D. J., Payne, T. G., and Gryc, George, 1959, Geology of possible petroleum provinces in Alaska, with an annotated bibliography by E. H. Cobb: U.S. Geol. Survey Bull. 1094, 131 p.

Miller, D. J., 1960, Giant waves in Lituya Bay, Alaska: U.S. Geol. Survey Prof. Paper 354-C, 86 p.

Molnia, B. F., 1976, Possible submarine ice-cored topography in the Bering Trough - NE Gulf of Alaska: Geol. Soc. America Abstracts with Programs, v. 8, p. 1016. 1977a, Rapid shoreline erosion and retreat at ICy Bay, Alaska - A staging area for offshore petroleum development: Proceedings, 1977 Offshore Technology Conference, v. 8, p. 115-126. 1977b, Coastal morphology, erosion and accretion of Gulf of Alaska coastline, Cape Suckling to Yakutat Bay: Geol. Soc. America Abstracts with Programs, v. 9, p. 1098.

Molnia, B. F., Carlson, P. R., and Bruns, T. R., 1977, Large submarine slide in Kayak Trough, Gulf of Alaska, in Landslides: Reviews in Engineering Geology: Geol. Soc. of America, v. 3, p. 137-148.

Molnia, B. F., Carlson, P. R., and Wright, I. H., 1978, Geophysical data from the 1975 cruise of the NOAA ship SURVEYOR, eastern Gulf of Alaska: U.S. Geol. Survey Open-file Report 78-209. 
Page, R. A., 1974, Evaluation of seismicity and shaking at offshore sites: Proceedings, 7th Offshore Technology Conference, Houston, Texas, v. 3, p. 179-190.

Post, Austin, and Mayo, I. R., 1971, Glacier dammed lakes and outburst floods in Alaska: U.S. Geol. Survey Hydrologic Atlas, HA-455.

Plafker, George, 1967, Surface faults on Montague Island associated with the 1964 Alaska earthquake, in The Alaska earthquake, March 27, 1964 -Regional effects: U.S. Geol. Survey Prof. Paper 543-G, P. GI-G42. 1969, Tectonics of the March 27, 1964 Alaska earthquake: U.S. Geol: Survey Prof. Paper 543-I, 74 p. (Also reprinted in NAS series on Alaska Earthquakes, Geology Volume; Seismology Volume). 1971, Pacific margin Tertiary basin, in Future petroleum provinces of North America: Am. Assoc. Petroleum Geologists Mem. 15, p. 120-135. 1972, Alaskan earthquake of 1964 and Chilean earthquake of 1960: Implications for arc tectonics: Jour. Geophys. Research, v. 77, p. $901-925$. 1974, Preliminary geologic map of Kayak and Wingham Islands, Alaska: U.S. Geol. Survey Open-file Map 74-82.

Plafker, George, Bruns, T. R., and Page, R. A., 1975, Interim report on the petroleum resource potential and geologic hazards in the outer Continental Shelf of the Gulf of Alaska Tertiary Province: U.S. Geol. Survey Open-file Report 75-592, 74 p.

Plafker, George, Hudson, Travis, Rubin, Meyer, and Bruns, Terry, 1978b, Late Quaternary offsets along the Fairweather fault and crustal plate interactions in southern Alaska: Canadian Jour. Earth Sci. (In press) 
Plafker, George, Winkler, G. R., Hunt, S. J., Bartsch-Winkler, Susan, Coonrad, W. L., and Quinterno, Paula, 1978a, Outcrop samples from the continental slope in the eastern Gulf of Alaska: U.S. Geol. Survey Circ. 772-B. (In press)

Rau, W. W., Plafker, George, and Winkler, G. R., 1977, Preliminary foraminiferal biostratigraphy and correlation of selected stratigraphic sections and wells in the Gulf of Alaska Tertiary Province: U.S. Geo1. Survey Open-file Report OF 77-747, 3 charts, 54 p.

Sykes, I. R., 1971, Aftershock zones of great earthquakes, seismicity gaps, and earthquake prediction for Alaska and the Aleutians: Jour. Geophys. Research, v. 75, p. 8021-8041.

Tarr. R. S., and Martin, Lawrence, 1912, The earthquakes at Yakutat Bay, Alaska in September, 1899: U.S. Geol. Survey Prof. Paper 69, 135 p. 


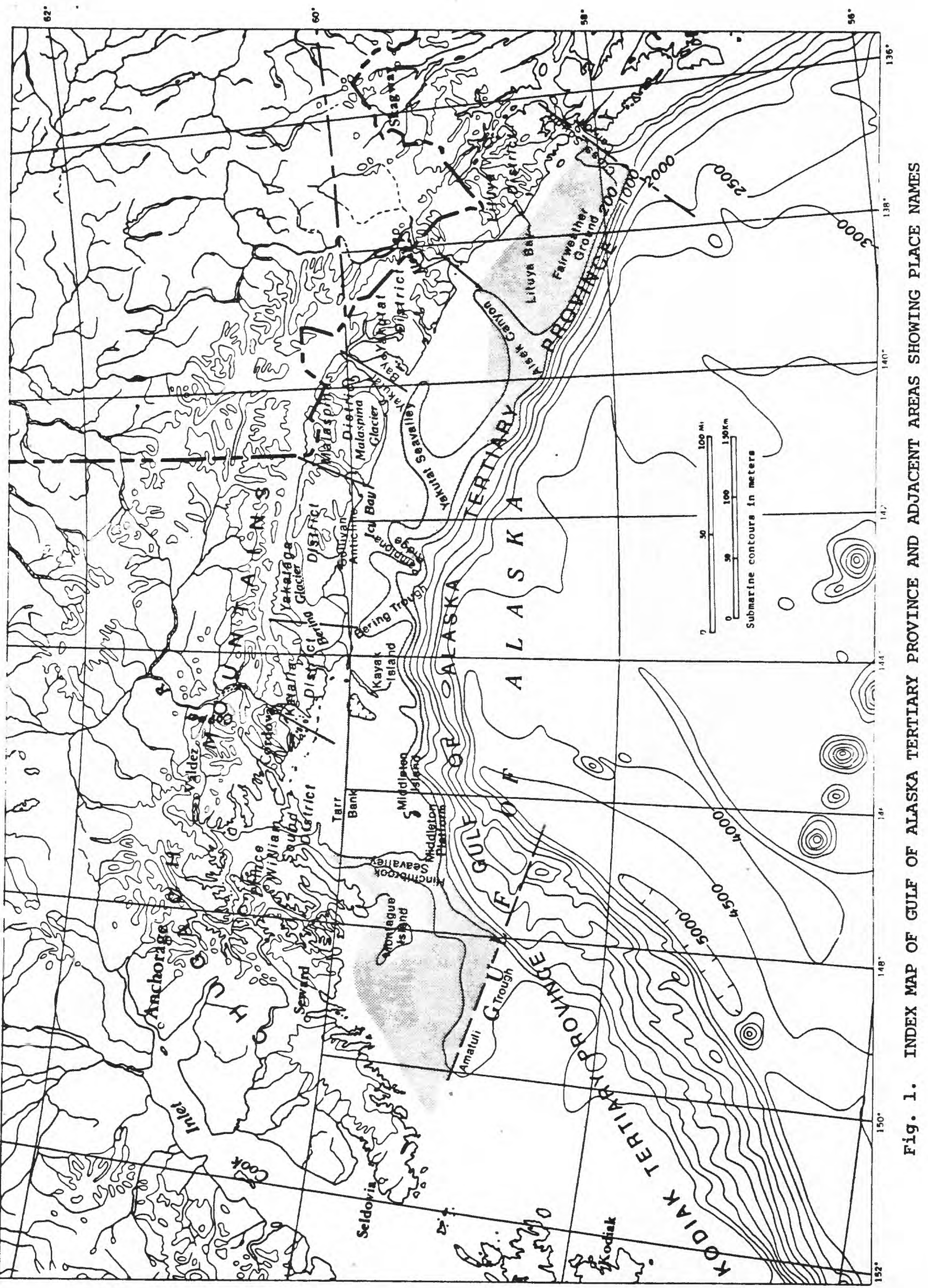




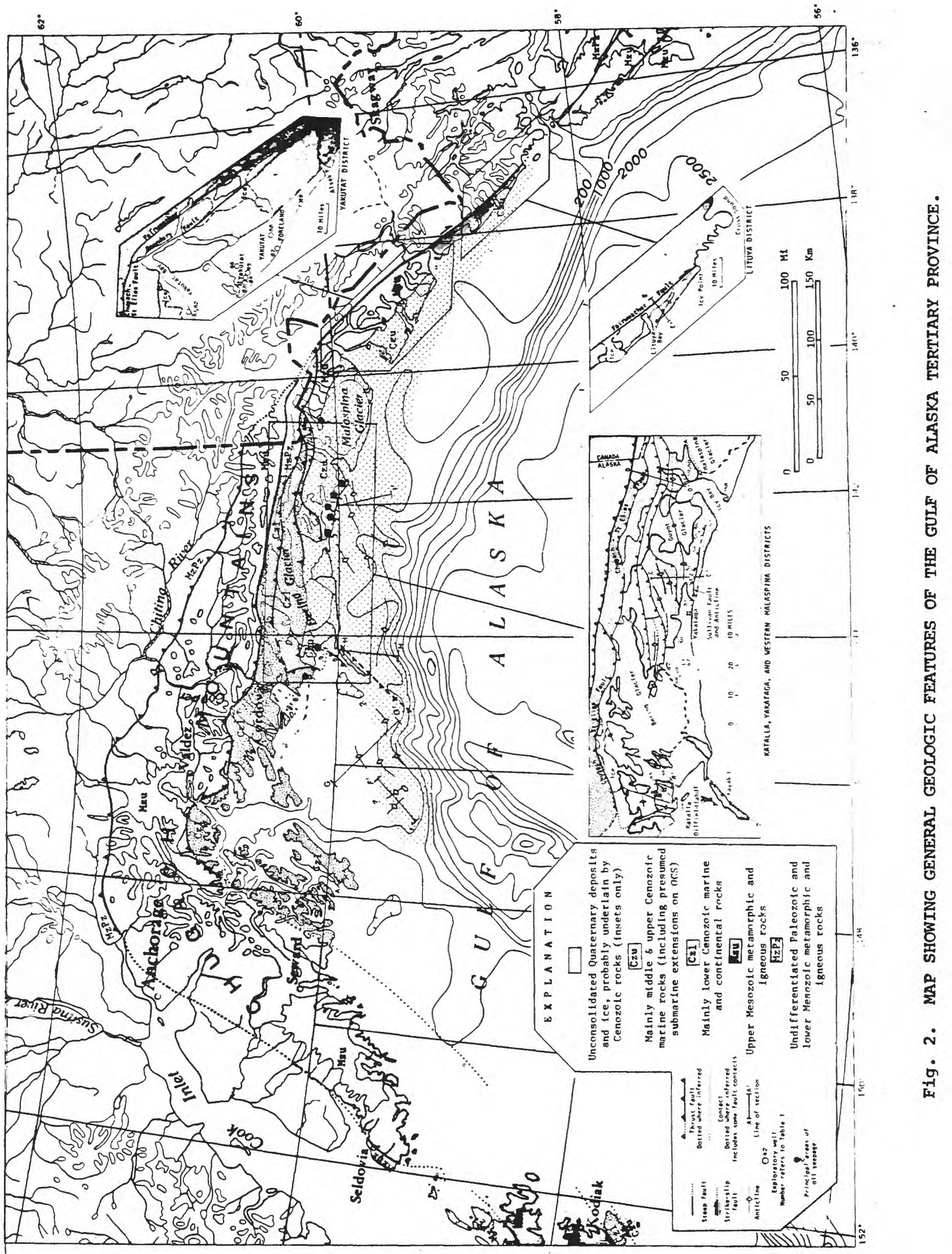




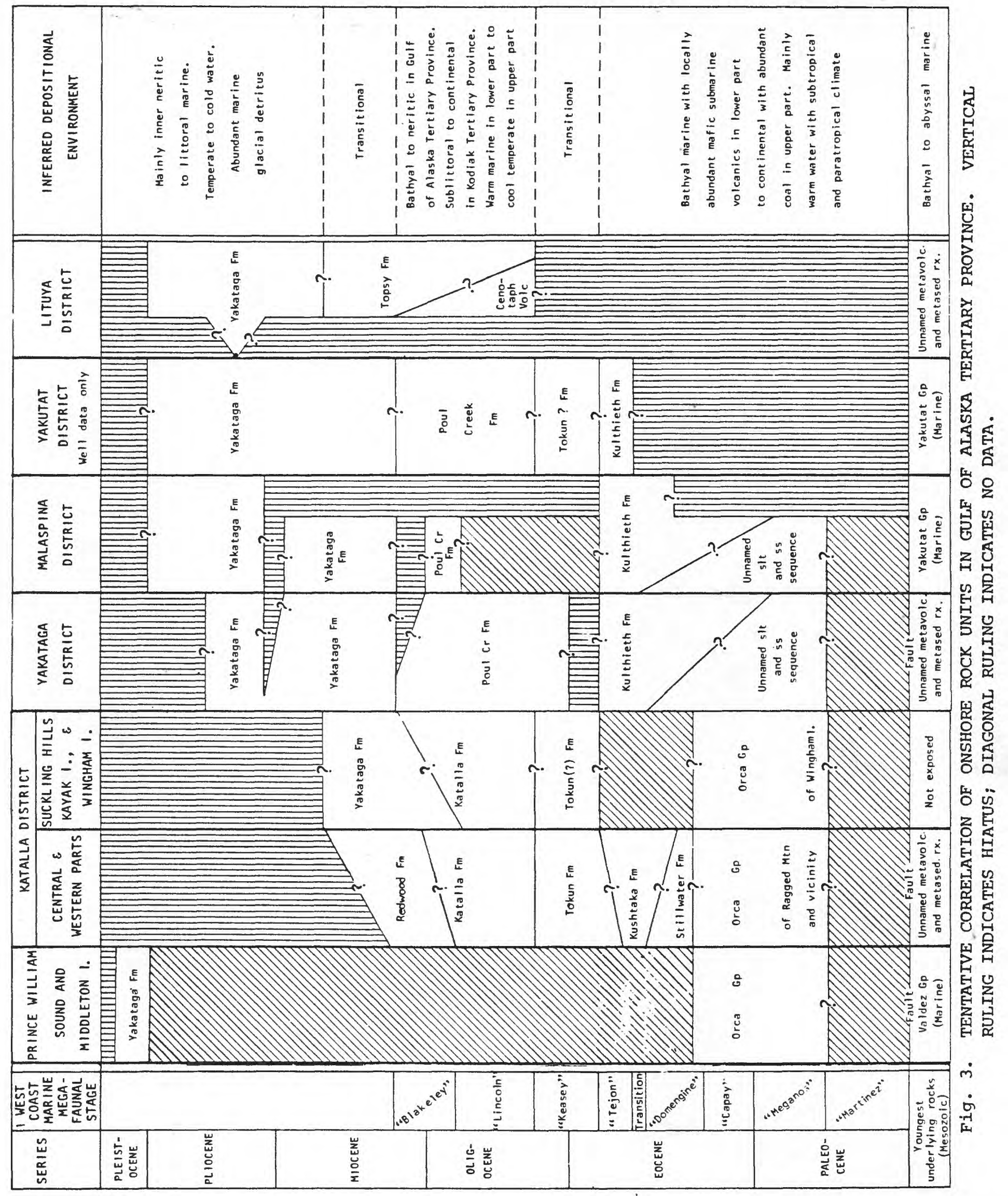




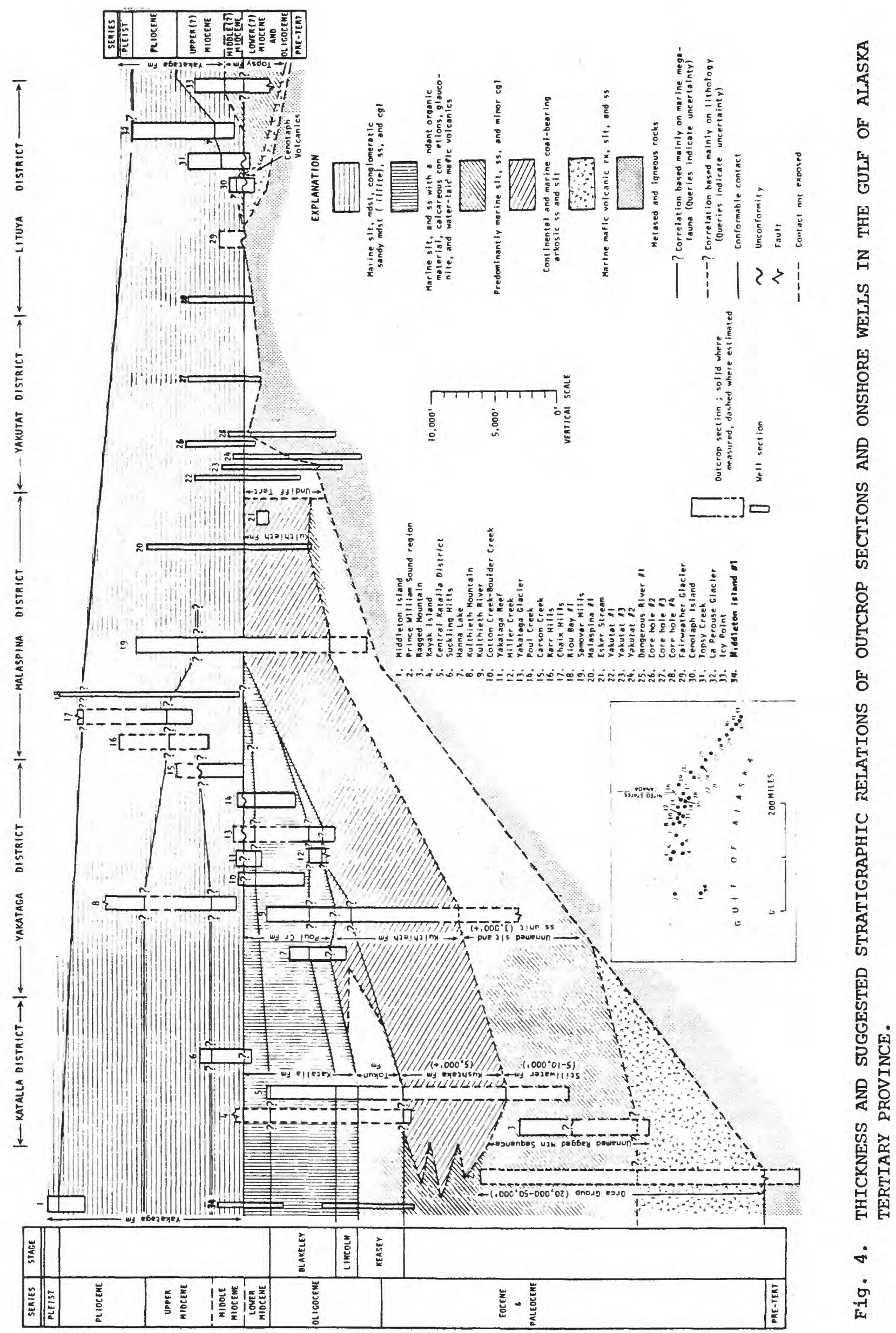




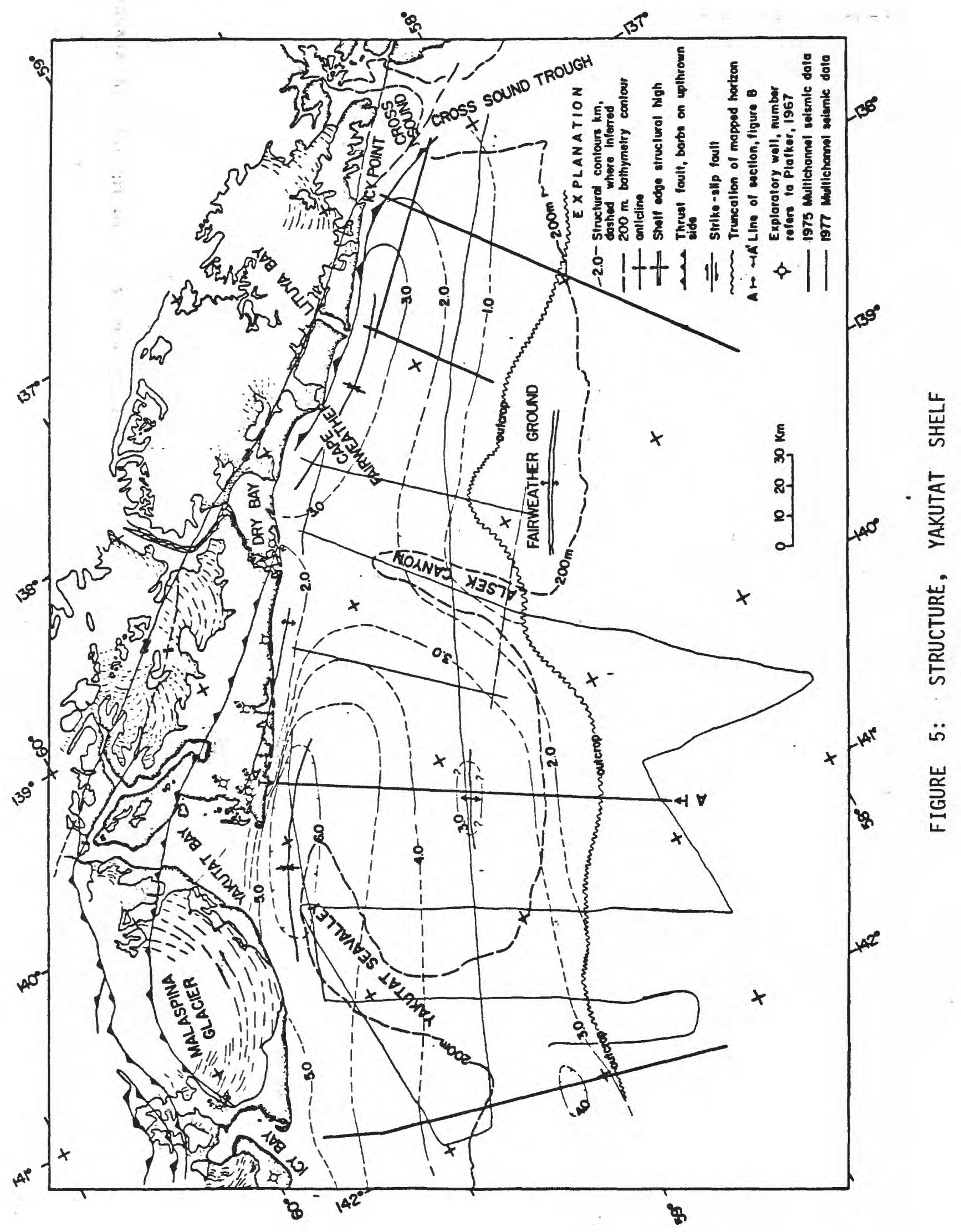




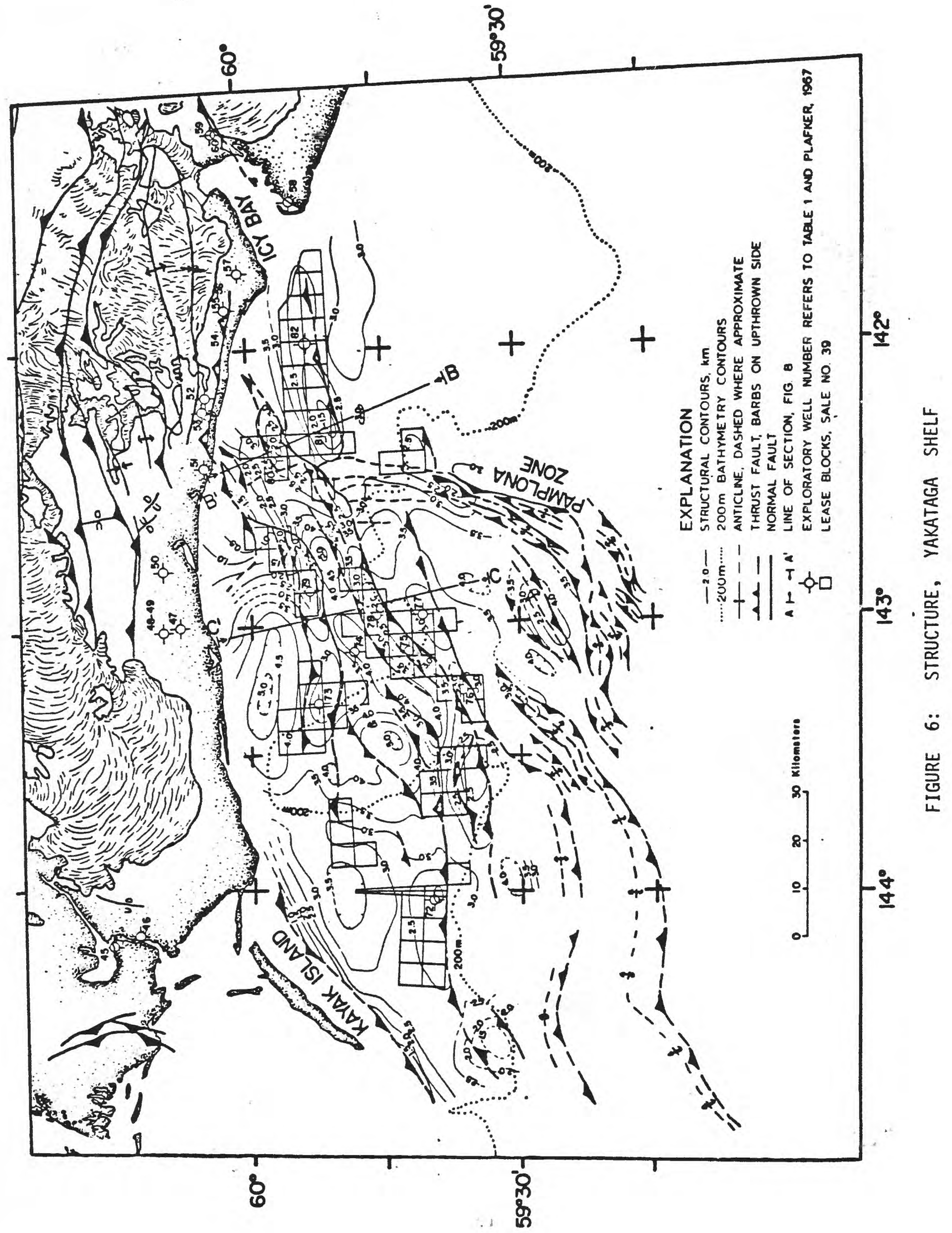




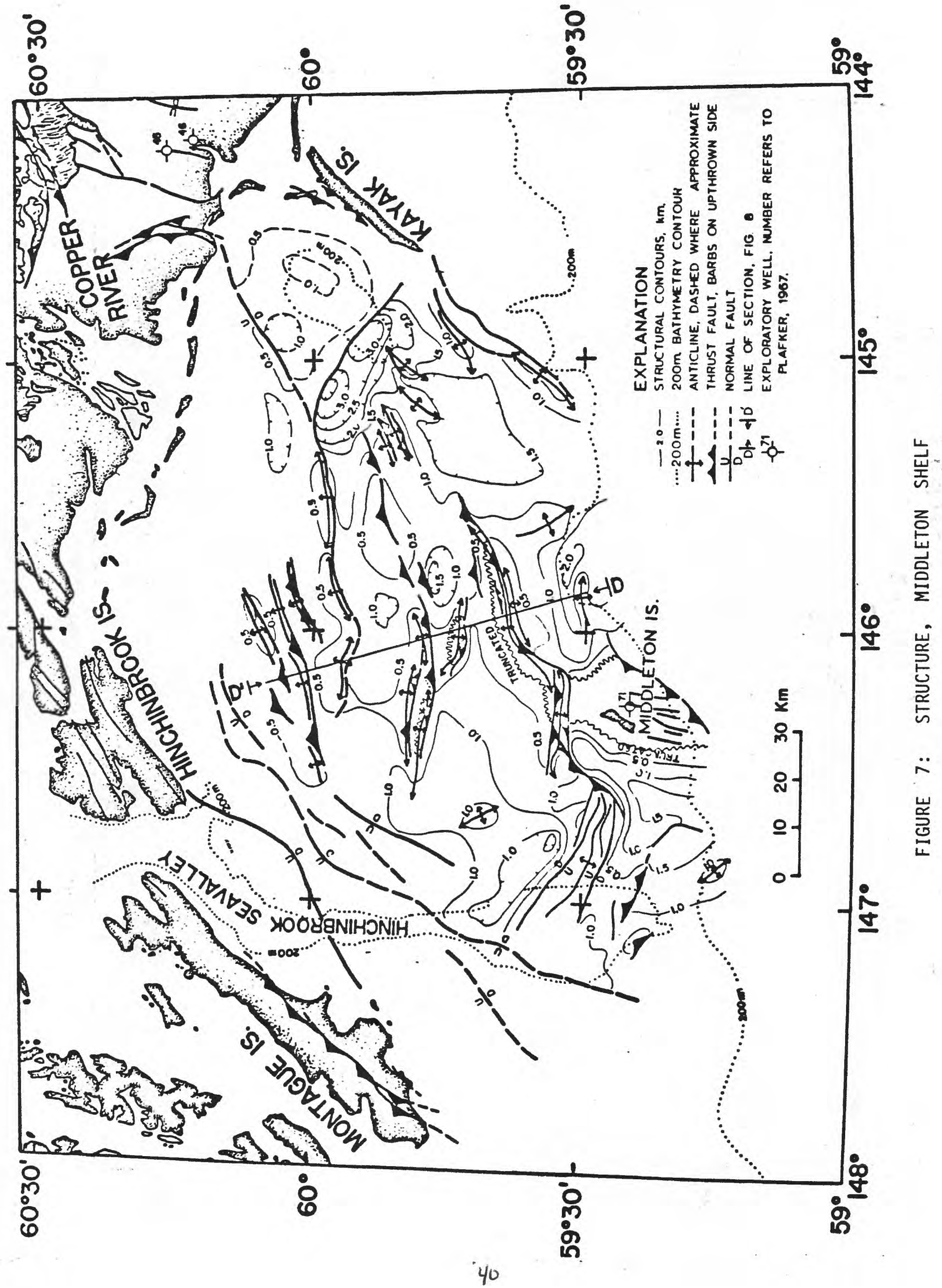



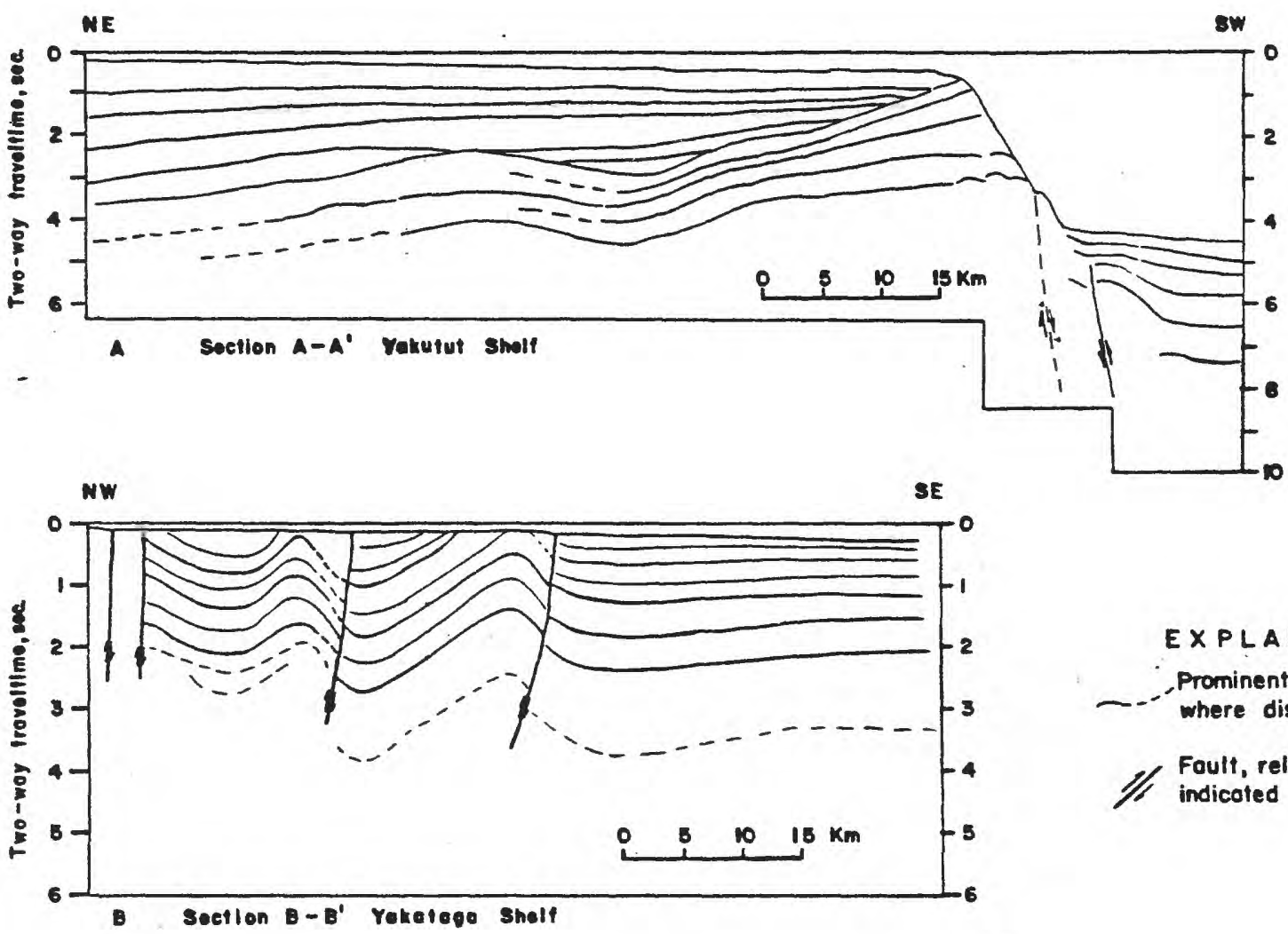

EXPLANATION

Prominent reflection, doshed where discontinuous

Foult, relative motion indicoted if known
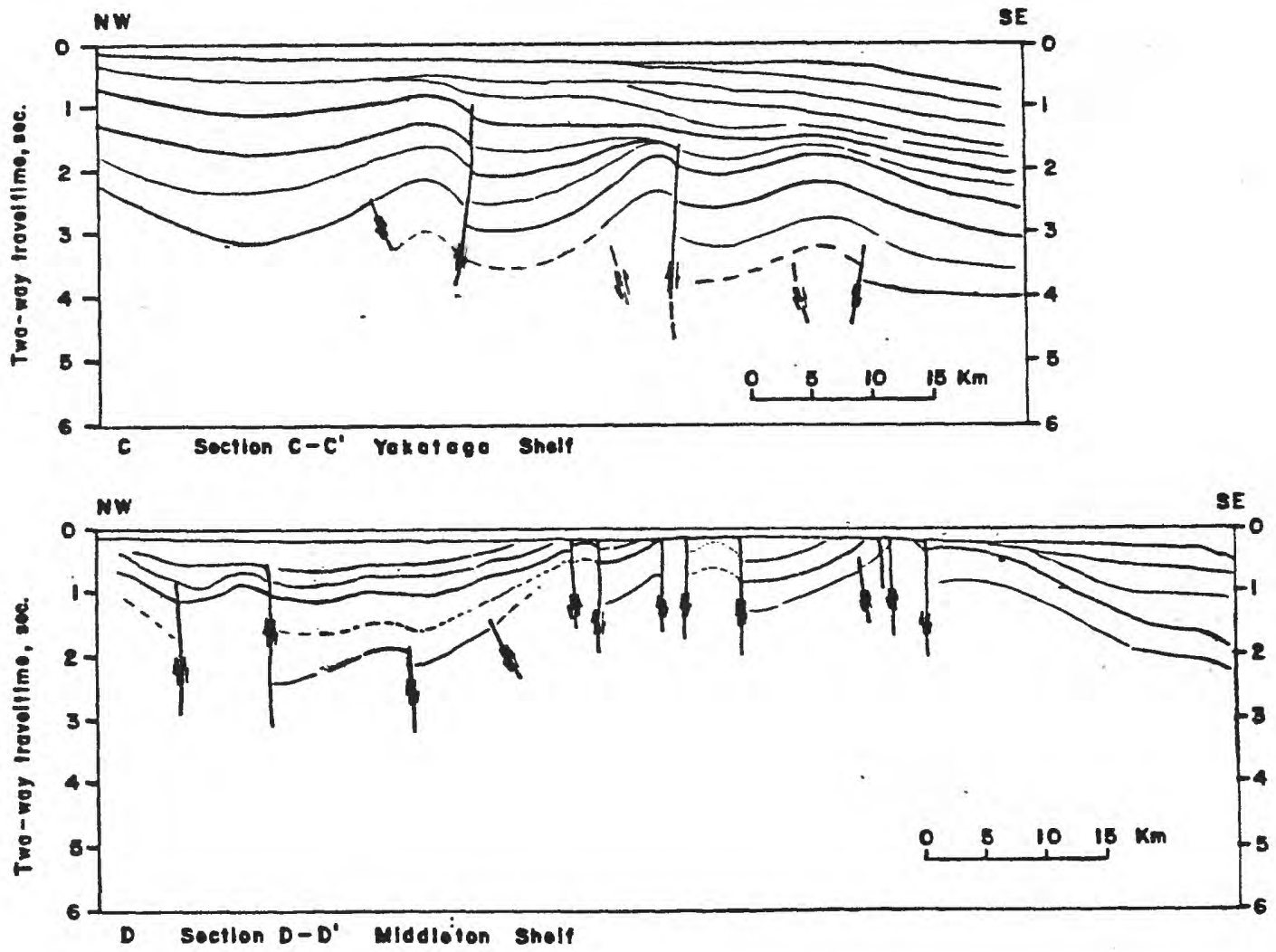

FIGURE 8. SIMPLIFIED INTERPRETATIVE LINE DRAWINGS; LOCATIONS SHOWN IN FIGURES 5-7. V.E. $5: 1$ AT SEAFLOOR 

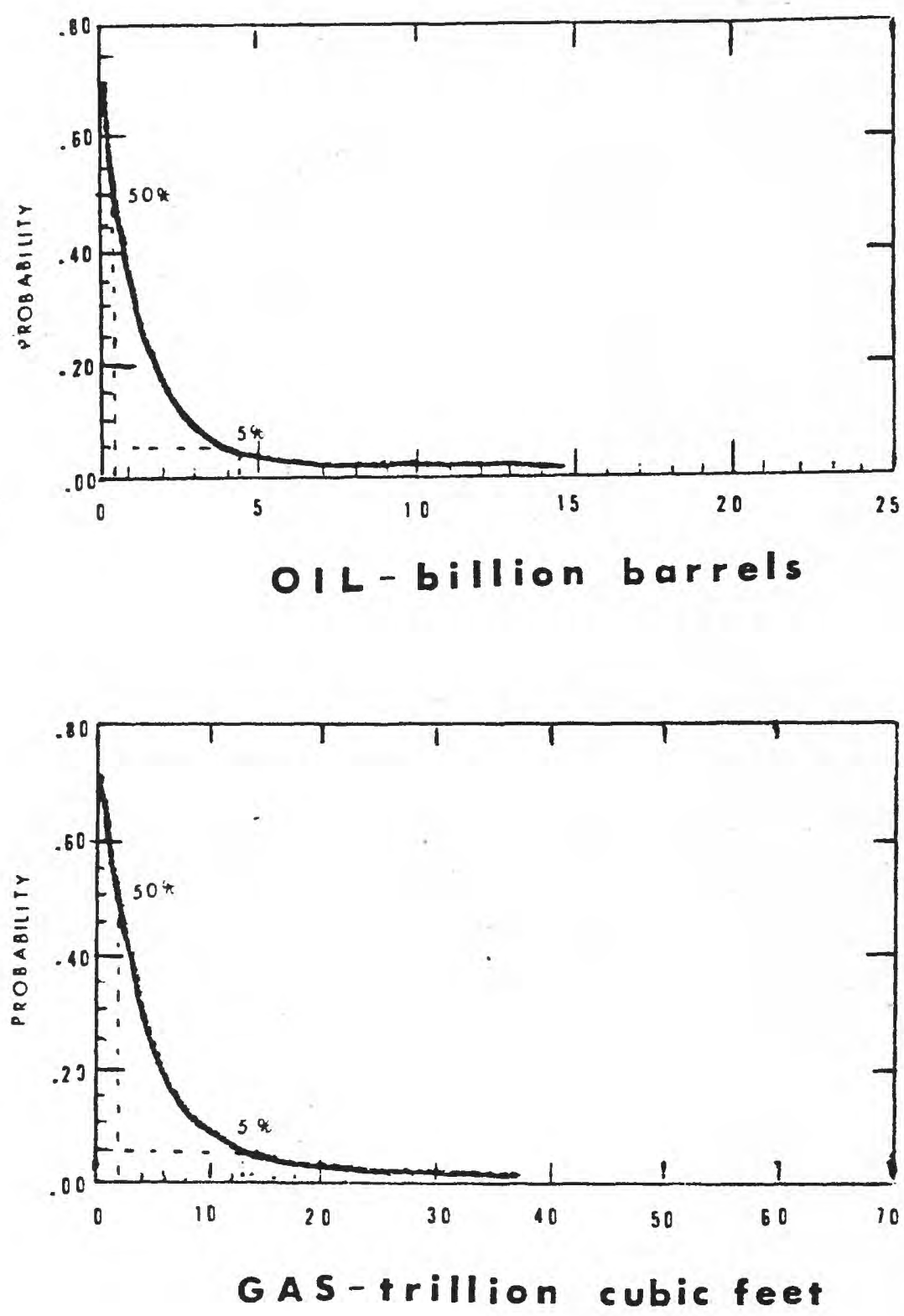

Fig. 9. IOGNORMAL PROBABIIITY DISTRIBUTION OF THE UNDISCOVERED RECOVERABLE OIL AND GAS RESOURCES FOR THE NORTHERN GULF OF ALASKA CONTINENTAL SHELF. 


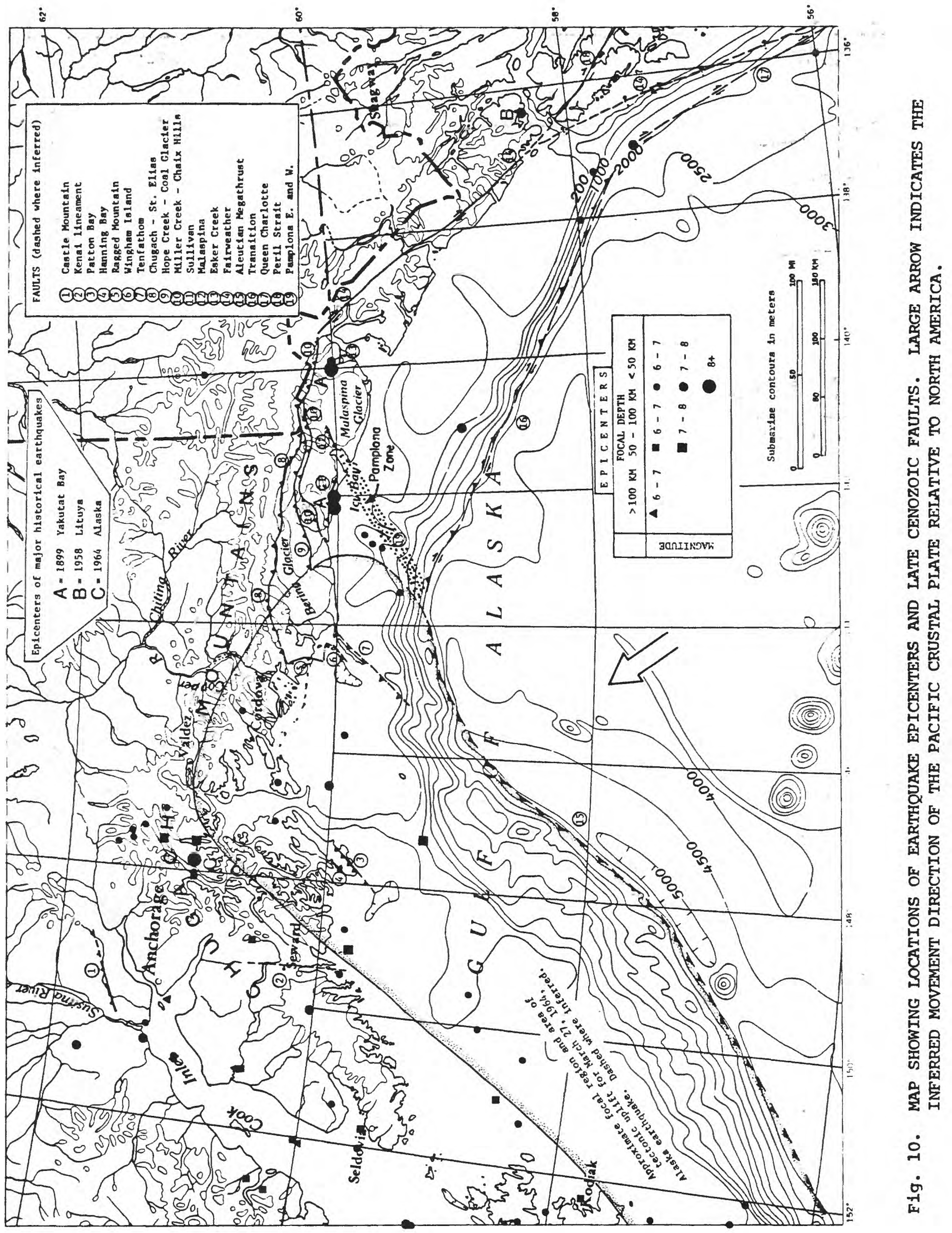




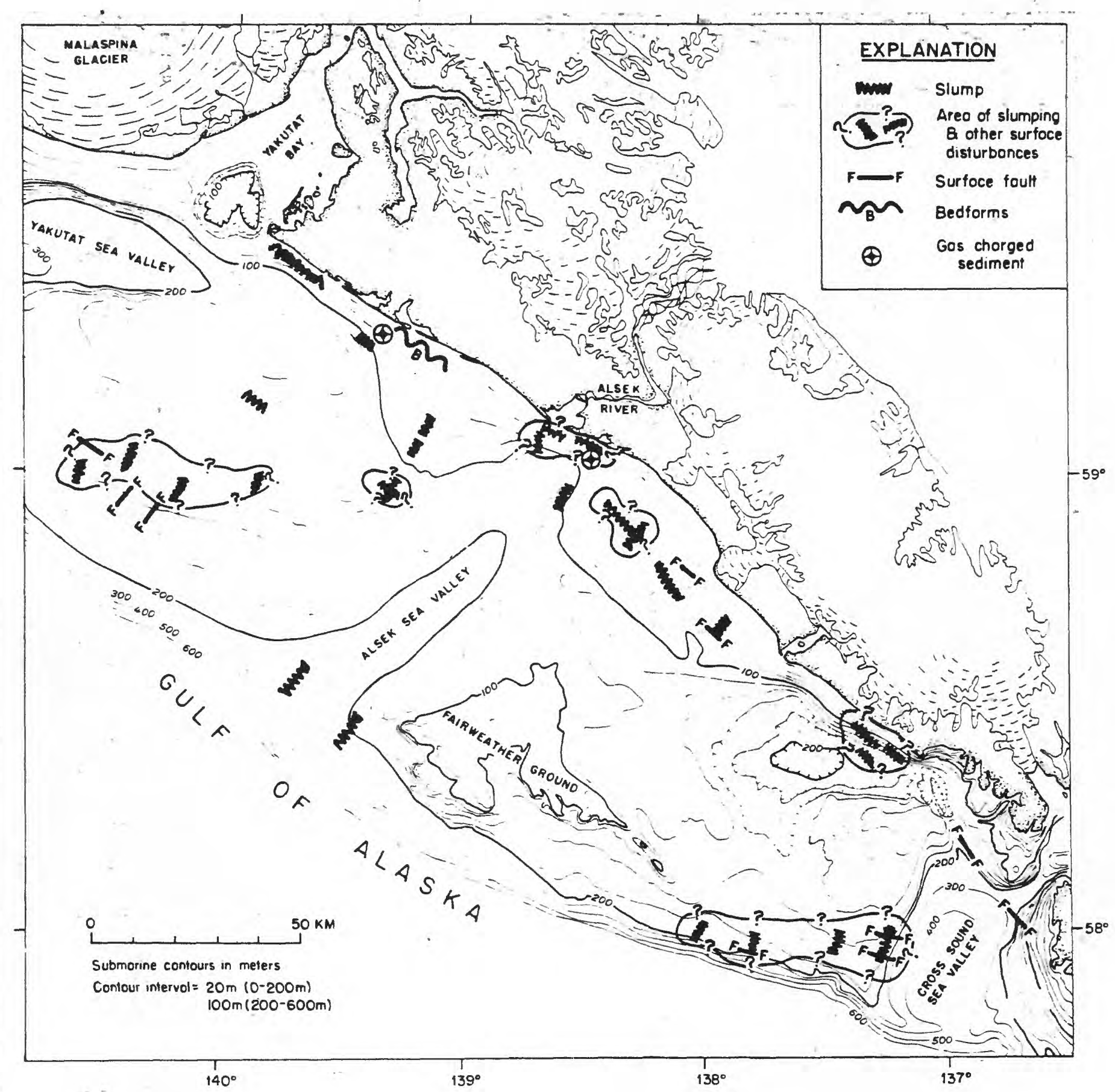

Fig. 11. ENVIRONMENTAL HAZARDS OF THE YAKUTAT SHELF. 


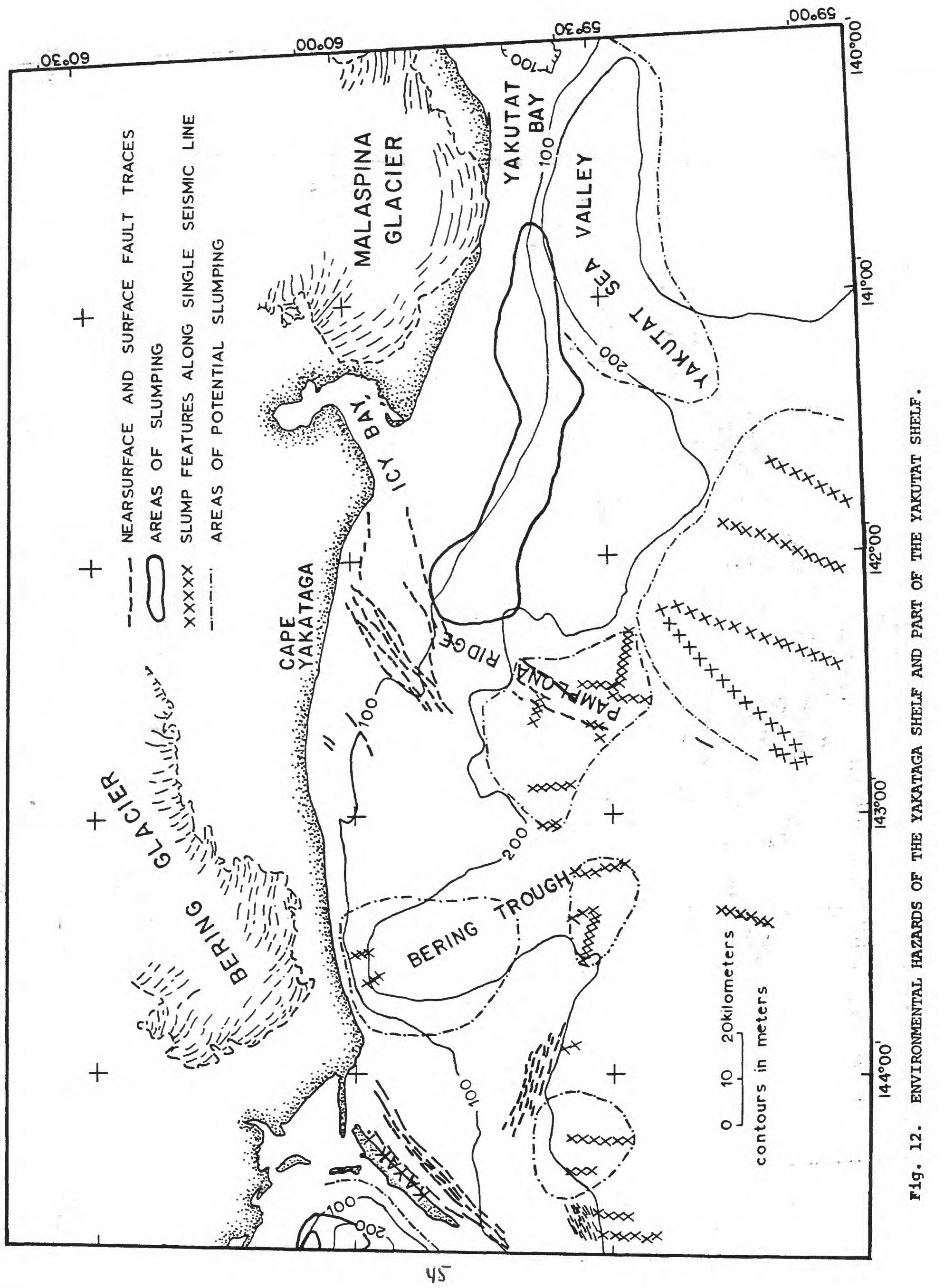




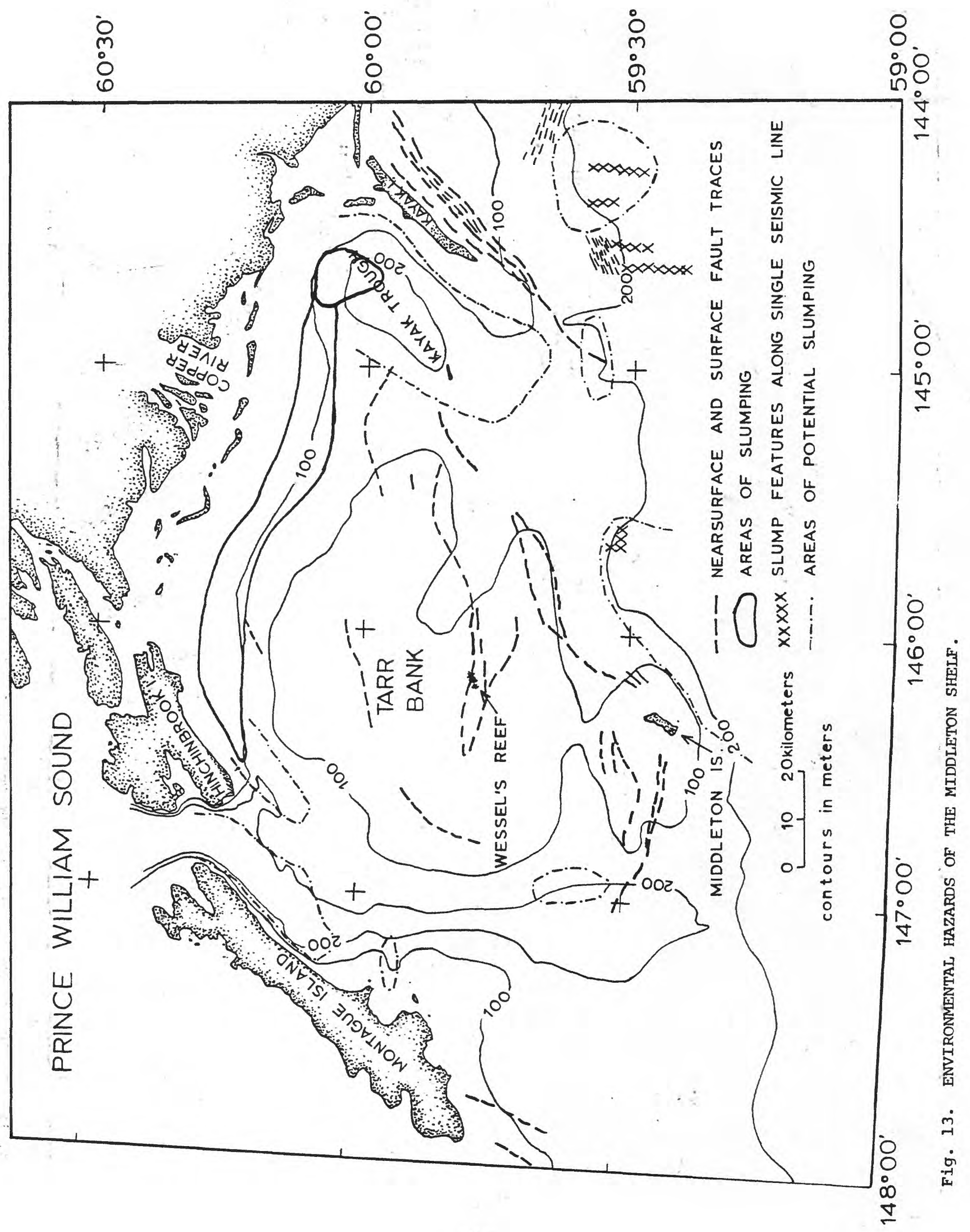

